\title{
ASEAN States, Their Reservations to Human Rights Treaties and the Proposed ASEAN Commission on Women and Children
}

\author{
Suzannah Linton*
}

\begin{abstract}
This article was inspired by claims made by a number of participants at the Fifth Workshop on an ASEAN Regional Mechanism on Human Rights in Kuala Lumpur (2006) that because all ASEAN states were party to the Convention on the Rights of the Child and the Convention on the Elimination of Discrimination against Women, they shared common legal obligations and so the path was clear for moving forward with the Hanoi Action Plan's Commission on Women and Children. At that time, it was not clear that ASEAN would go any further than this commission. This article is therefore an examination of the law on reservations, but one that has at its core an examination of ASEAN states' reservations to the six main human rights treaties in light of Vienna Convention on the Law of Treaties. Analysis is situated in the on-going debate about reservations to human rights treaties, as well as assessment of the significance and impact of the ASEAN reservations in themselves, in relation to other state parties, on the proposed Commission on Women and Children, and on international law generally. Since this article was written, ASEAN adopted a new Charter for the organization, which, in Article 14, allows for the creation of a human
\end{abstract}

\footnotetext{
* Suzannah Linton is an Associate Professor, Director of the LL.M. in Human Rights Programme and Deputy Director of the Centre for Comparative and Public Law at the University of Hong Kong.

A shorter version of this article was presented at the inaugural conference of the Asian Society of International at the National University of Singapore in April 2007. President Rosalyn Higgins of the International Court of Justice and Professors Hurst Hannum and Roger Clark gave excellent suggestions, for which I am deeply grateful. I am also very appreciative of the able assistance, particularly with editing, of Firew Kebede Tiba. Thanks also to Xia Chunli, Karen Lee, and Xu Yan for assisting with some of the data used.
} 
rights body, to operate in accordance with terms of reference yet to be decided by the Foreign Ministers of ASEAN. The Commission on Women and Children has yet to be established.

\section{INTRODUCTION}

On 13 January 2007, the political leaders of the Association of South East Asian Nations (hereafter ASEAN) ${ }^{1}$ met in Cebu in the Philippines and adopted a declaration approving the blueprint of a charter for creating a new ASEAN Community by 2015. ${ }^{2}$ The blueprint, prepared by the Eminent Persons Group, made a startling (by ASEAN standards) sixteen references to human rights and five to international humanitarian law. Further, it expressed support for plans to establish an ASEAN Commission on Women and Children and encouraged member states to further pursue the "worthy idea" of an ASEAN human rights mechanism that "can contribute to ensuring the respect for and protection of human rights of every individual in every Member State." ${ }^{3}$

The ASEAN approach subscribes to the notion that there is a body of supranational universally binding legal norms that protect the human person from arbitrary encroaches by the state. ${ }^{4}$ This shift towards human rights began with the Bangkok Declaration that reiterated the need to explore "the possibilities of establishing regional arrangements for the promotion and protection of human rights in Asia." ${ }^{5}$ This led to ASEAN states agree-

1. The Association of Southeast Asian Nations (ASEAN) was established on 8 Aug. 1967 in Bangkok by the five original Member Countries: Indonesia, Malaysia, Philippines, Singapore, and Thailand. Brunei Darussalam joined on 8 Jan. 1984, Vietnam on 28 July 1995, Lao PDR and Myanmar on 23 July 1997, and Cambodia on 30 April 1999. Available at http://www.aseansec.org/64.htm.

2. The Cebu Declaration endorsed the Report of the Eminent Persons Group on the ASEAN Charter, Dec. 2006. Cebu Declaration on the Blueprint of the ASEAN Charter, 13 Jan. 2007, available at http://www.aseansec.org/19257.htm.

3. The report also recommended including active strengthening of the rule of law including international humanitarian law, and respect for human rights and fundamental freedoms as its fundamental principles and objectives in the Charter. Report of the Eminent Persons Group on the ASEAN Charter, Dec. 2006, ๆ 47, available at http://www.aseansec. org/19247.pdf.

4. See The Report of the Regional Meeting for Asia of the World Conference on Human Rights, Bangkok, 29 Mar.-2 Apr. 1993, U.N. Doc.A/CONF.157/ASRM/8, A/CONF.157/ PC/59, 7 Apr. 1993 (hereafter Bangkok Declaration). For Lee Kuan Yew's arguments about Asian Values, see Fareed Zakaria, Culture is Destiny: A Conversation with Lee Kuan Yew, For. Aff.109 (Mar.-Apr. 1994); see also Mahathir Mohamad \& Shintaro Ishihara, The Voice of Asia: Two Leaders Discuss the Coming Century (Frank Baldwin trans. 1995). Compare Amartya Sen, Human Rights and Asian Values: What Lee Kuan Yew and Le Peng Don't Understand About Asia, 217 The New Republic 33 (1997); Yash Ghal, Human Rights and Governance: The Asia Debate (Asia Foundation Occasional Paper No. 4, 1994); Li-ann Thio, Implementing Human Rights in ASEAN Countries: "Promises to keep and miles to go before I sleep," 2 Yale Hum. Rts. \& Dev. L. J. 1 (1999).

5. Bangkok Declaration, supra note 4, ब 26. 
ing to the Vienna Declaration in 1993. These states joined other states in agreeing that:

All human rights are universal, indivisible and interdependent and interrelated. The international community must treat human rights globally in a fair and equal manner, on the same footing, and with the same emphasis. While the significance of national and regional particularities and various historical, cultural and religious backgrounds must be borne in mind, it is the duty of States, regardless of their political, economic and cultural systems, to promote and protect all human rights and fundamental freedoms. ${ }^{6}$

Shortly after, at the twenty-sixth ASEAN Ministerial Meeting in Singapore in 1993, the foreign ministers declared themselves to be "in support of the Vienna Declaration and Programme of Action of June 25, 1993" and "agreed that ASEAN should also consider the establishment of an appropriate regional mechanism on human rights." ${ }^{\prime 7}$ Thereafter, the Joint Communiqué began a brief regional effort in human rights at almost every ASEAN Ministerial Meeting thereafter. Turning the tide has been possible thanks in part to the indefatigable work of civil society (specifically, the Working Group for an ASEAN Human Rights Mechanism) ${ }^{8}$ who have patiently tuned in to the painfully slow step-by-step approach that ASEAN states favor and the UN building blocks approach. ${ }^{9}$ ASEAN states are now party to many human rights and humanitarian law conventions, and are subject to the external scrutiny of treaty and non-treaty human rights bodies. Even Singapore, Malaysia, and Myanmar report to treaty monitoring bodies. The Philippines is the first ASEAN state to allow its citizens the right to directly petition the Human Rights Committee, a human rights treaty body. ${ }^{10}$ Perhaps the Cebu Declaration will indeed lead to what the Office of the High Commissioner

6. Vienna Declaration and Programme of Action, U.N. GAOR, World Conf. on Hum. Rts., 48th Sess., 22d plen. mtg., part I, I 5, U.N. Doc. A/CONF.157/24 (1993), reprinted in 32 I.L.M. 1661 (1993).

7. Joint Communique of the Twenty-Sixth ASEAN Ministerial Meeting Singapore, 23-24 July 1993, available at http://www.aseansec.org/2009.htm.

8. There are interesting parallels to be drawn between ASEAN's transnational advocacy networks, and those that developed in Latin America and caused what is called the "justice cascade" punching a hole through impunity for human rights violations paving the way for the Pinochet litigation. See Ellen Lutz \& Kathryn Sikkink, The Justice Cascade: The Evolution and Impact of Foreign Human Rights Trials in Latin America, 2 ChICAgo J. INT'L L. 1 (2001).

9. These building blocks involve four key activities: promoting human rights action plans, supporting establishment of national human rights institutions, fostering human rights education, and realizing economic social and cultural rights and the right to development.

10. As of 3 May 2004, there had been nineteen such communications to the Human Rights Committee since the Philippines acceded to the Optional Protocol to the International Covenant on Civil and Political Rights on 22 Aug. 1989. Statistical survey available at http://www.unhchr.ch/html/menu2/8/stat2.htm. 
for Human Rights Regional Office in Bangkok considers its "highest priority" - the establishment of an ASEAN regional human rights mechanism. ${ }^{11}$

The establishment of an ASEAN commission on the promotion and protection of the rights of women and children by 2010 was initially proposed in the hope that it would serve as a catalyst, or an "entry point," for a regional human rights mechanism. ${ }^{12}$ If it is to have any teeth, an ASEAN Commission on Women and Children must involve some form of multilateral treaty with states entering into legally binding obligations. Work has been done on advancing this concept since it was adopted in ASEAN's Vientiane Action Programme of 2004. ${ }^{13}$ The Working Group for an ASEAN Human Rights Mechanism has been asked to assist ASEAN states in implementation of the human rights aspects of the program; at the time of this writing was working on a proposal to submit to ASEAN at the Senior Officials Meeting in Manila in 2007. Expert consultations at the ASEAN level were held, in Bangkok in November 2006. ${ }^{14}$ The concept is being analyzed in consultation with civil society and experts. They are identifying relevant domestic legislation, policies, and institutions in ASEAN, as well as on the basic conceptual design and mandate. The focus is on domestic law in ASEAN states. ${ }^{15}$

There is an assumption that because all ASEAN states have signed up to the two specialized treaties dealing with women and children, respectively the Convention on the Elimination of Discrimination against Women (CEDAW) ${ }^{16}$

11. Homayoun Alizadeh, OHCR's Role in Supporting the Establishment of an ASEAN Regional Human Rights Mechanism, paper presented to the Second Asia Human Rights Forum on Regional Human Rights Co-operation for Combating Commercial Sexual Exploitation of Children in Asia, Seoul, South Korea (5 Feb. 2007) (on file with author).

12. Vitit Muntarbhorn, A Roadmap for an ASEAN Human Rights Mechanism, prepared at the third workshop for an ASEAN Regional Mechanism on Human Rights, Bangkok, Thailand, 28-29 May 2003, available at http://www.fnf.org.ph/liberallibrary/roadmapfor-asean-human-rights.htm.

13. Vientiane Action Programme (2004-2010), agreed at the $10^{\text {th }}$ ASEAN Summit in Vientiane, 29 Nov. 2004, as the successor to the Hanoi Plan of Action, available at http://www. aseansec.org/VAP-10th\%20ASEAN\%20Summit.pdf.

14. See the record of discussion in the Report of the Expert Meeting on the Establishment of an ASEAN Commission for the Promotion and Protection of the Rights of Women and Children, 20 Nov. 2006, Bangkok, Thailand [hereinafter Report of the Expert Meeting on the Establishment of an ASEAN Commission for the Promotion and Protection of the Rights of Women and Children] (on file with author).

15. See Raj Abdul Karim, Efforts to Help Establish a Commission on the Promotion and Protection of the Rights of Women and Children and Steps to Be Undertaken, paper presented to the Fifth Workshop on the ASEAN Regional Mechanism on Human Rights, 29-30 June 2006, Kuala Lumpur, Malaysia. This presentation focused solely on surveys of existing domestic laws, policies, and institutions regarding the rights of women and children (on file with the author).

16. Convention on the Elimination of All Forms of Discrimination Against Women [hereinafter CEDAW], adopted 18 Dec. 1979, G.A. Res. 34/180, U.N. GAOR, 34th Sess., Supp. No. 46, U.N. Doc. A/34/46 (1980) (entered into force 3 Sept. 1981), 1249 U.N.T.S. 13, reprinted in 19 I.L.M. 33 (1980). There is also an Optional Protocol to the convention dealing with communications and greater investigative powers for the monitoring body. Within ASEAN, the Philippines and Thailand are parties. 
and the Convention on the Rights of the Child (CRC), ${ }^{17}$ that there is a common legal standard and there can be no dispute over the jurisdiction ratione materiae of a commission. That is not correct. The CRC is now accompanied by two protocols, one on children in armed conflict $^{18}$ and the other on the sale of children, child prostitution, and child pornography. ${ }^{19}$ More importantly, CEDAW and CRC are among the most heavily reserved of all the human rights treaties, with certain ASEAN states, such as Singapore, Brunei Darussalam, Thailand, and Malaysia, entering very substantial general reservations. On the other hand, there are some ASEAN states that have seen no need to enter or maintain reservations, such as the Philippines, Indonesia, Cambodia, and Lao PDR. There has been no "common ASEAN position" in this matter. Each state has acted in accordance with its own interests and concerns. It bears recalling that with human rights being indivisible and inter-linked, women and children in ASEAN are also the beneficiaries of rights that some of their states have committed to protect under other human rights treaties, such as the International Covenant on Civil and Political Rights (ICCPR) and the International Covenant on Economic Social and Cultural Rights (ICESCR), and under certain international humanitarian law treaties such as the Geneva Conventions of 1949. At least one ASEAN state (Thailand) has become tangled in inconsistencies between its different treaty obligations.

This article seeks to make a modest contribution towards the process by considering the impact that the international obligations arising from treaty participation and reservations by ASEAN states could have upon the proposed Commission on Women and Children. The author takes no position on the wisdom of separating out women and children as one collectivity, as opposed to holding out for a full-blown human rights convention implemented with the assistance of judicial enforcement. ${ }^{20}$ Neither is a position taken on whether there should be two separate commissions each looking at a different issue, rather than one that looks at both women and children. The complex reservations regime in the Vienna Convention on the Law of

17. Convention on the Rights of the Child [hereinafter CRC], adopted 20 Nov. 1989, G.A. Res. 44/25, U.N. GAOR, 44th Sess., Supp. No. 49, U.N. Doc. A/44/49 (1989) (entered into force 2 Sept. 1990), reprinted in 28 I.L.M. 1448 (1989).

18. Optional Protocol to the CRC on the involvement of children in armed conflict, adopted 25 May 2000, G.A. Res. 54/263, U.N. GAOR, 54th Sess., Supp. No. 49, U.N. Doc. A/54/49 (2000), (entered into force 12 Feb. 2002).

19. Optional Protocol to the CRC on the sale of children, child prostitution and child pornography, adopted 25 May 2000, G.A. Res. 54/263, U.N. GAOR, 54th Sess., Supp. No. 49, U.N. Doc. A/54/49 (2000), (entered into force 18 Jan. 2002).

20. One can note that the South Asian Association for Regional Cooperation (SAARC), comprising Bangladesh, Bhutan, India, Maldives, Nepal, Pakistan, and Sri Lanka, has adopted Conventions on the Preventing and Combating Trafficking in Women and Children, and on Regional Arrangements for the Promotion of Child Welfare in South Asia. Neither is supported by a monitoring mechanism. 
Treaties (Vienna Convention) ${ }^{21}$ forms the backdrop, with closer consideration of the particularly thorny issue of reservations to human rights treaties and the ongoing controversies in that area. The discussion will move to the presentation and analysis of data about the reservations of ASEAN states, by focusing narrowly on CEDAW and CRC. This narrow focus is necessitated by lengthy restrictions and the need to conduct meaningful analysis of the state of ASEAN reservations rather than skimming through them. Some of these reservations have been objected to by other states or treaty monitoring bodies as invalid for being incompatible with the object and purpose of the treaties. However, these reservations do comprise the terms under which ASEAN states are prepared to give their consent to be bound by treaties. What then are the treaty obligations of ASEAN states in such circumstances? This leads us to the final consideration of the implications of these reservations for the proposed Commission on Women and Children.

\section{SETTING THE CONTEXT: WHY DO ASEAN STATES BECOME PARTY TO HUMAN RIGHTS TREATIES?}

Singapore has made all of its international obligations subject to Singaporean law and the constitution, and made it clear that the "accession to the convention by the Republic of Singapore does not imply the acceptance of obligations going beyond the limits prescribed by the Constitution of the Republic of Singapore nor the acceptance of any obligation to introduce any right beyond those prescribed."22 Brunei and Malaysia have also subjected obligations to Islamic and domestic law. Why do such states then bother with joining a treaty if everything is to be maintained at the existing standard?

Li-ann Thio has argued that ASEAN participation in human rights treaties "displays a degree of good will" on their part, a commitment to international rule of law, and "signals to the citizenry that its government is not out of step with international mores (insofar as they are reflected by human rights) or that it is in fact 'liberalizing' and answering the call to accountability." ${ }^{23}$ The UN driven trend towards universal ratification of the principal human rights treaties has been clearly discernable for some years; ${ }^{24}$ and is now becoming

21. Vienna Convention on the Law of Treaties, U.N. Doc. A/CONF.39/27 (1969), 1155 U.N.T.S. 331, (entered into force 27 Jan. 1980), reprinted in 8 I.L.M. 679 (1969).

22. Singapore's reservation to Convention on the Rights of the Child, 5 Oct. 1995, I 3, available at http://untreaty.un.org/humanrightsconvs/Chapt_IV_11/reservations/singapore. pdf.

23. Thio, supra note 4 , at 28.

24. See Philip Alston, Final Report on Enhancing the Long-Term Effectiveness of the United Nations Human Rights Treaty System, U.N. Doc. E/CN.4/1997/74 (27 Mar. 1997), argu- 
part of the discourse in ASEAN. Some of the states that ratify these treaties, such as Myanmar and Laos, face enormous challenges of implementation if the pacta sunt servanda rule is to be honored. At a minimum, there needs to be a legal infrastructure and understanding about the implications of treaty participation within the legislature, judiciary, executive, and by the ordinary citizen. Take for example, the connected rights to a fair trial and due process. They cannot be achieved overnight and are extremely costly. Arrest, detention, and investigation procedures need to be aligned with international standards. The court system must be calibrated to enable trial before a competent, independent, and impartial tribunal administering a fair trial with due process. These same standards apply to appeals to higher courts. It also includes conditions in penitentiaries (should an accused be convicted and sentenced to a custodial sentence) and the right to an effective remedy if rights have been violated in the process. Such obligations are extremely onerous for developing countries. Do states that ratify human rights treaties have any intention of meeting their commitments? What motivates states to take on such heavy legally binding obligations? Have they genuinely embraced the value system that underpins the human rights paradigm, or are these just hollow self-interest driven gestures?

International relations theorists offer some possibilities to assist our understanding. Sometimes states enter treaties to relieve the pressures from other states, from influential supranational political entities, or from their own communities. The regional context can be very influential because "regional political and economic interdependence generates greater external pressure on countries to exhibit a commitment to human rights norms." ${ }^{25}$ Basing his study on post-war Europe, which also has some resonances in Southeast Asia, Professor Andrew Moravcsik has argued that states accept binding human rights treaties mainly as a means of political survival; in situations of transition to liberal or democratic societies, states are most likely to ratify human rights instruments to protect the still fragile regime against non-democratic opponents. ${ }^{26}$ They create institutions as a rational and self-interested move to selectively delegate sovereignty to a supranational body to secure the desired domestic outcome of enhanced democratic governance. Their participation in human rights treaties acts to keep the new regime in power and protects anti-democratic forces, and solidifies the democratic state; and also locking in the policy preference of democracy.

ing that universal ratification of the six core human rights treaties is the best possible foundation for international endeavors to promote respect for human rights.

25. Oona A. Hathaway, Do Human Rights Treaties Make a Difference?, 111 Yale L.J. 1935, 2020 (2001-2002).

26. Andrew Moravcsik, The Origins of Human Rights Regimes: Democratic Delegation in Postwar Europe, 54 INT'L OrG. 217 (2000). 
Ideational theorists argue that states change their behavior because of the costs of deviance from the norms of international society, "changing models of appropriate and legitimate statehood, and because the political pressures of other states and non-state actors affect their understanding of their identity and standing in the international community of states." ${ }^{27}$ In this approach, human rights norms and treaties are particularly important because good compliance signals to other states that a state belongs to the community of law-abiding, democratic states.

Another theory, relevant to some ASEAN nations, argues that ratification of human rights treaties serves as a signaling device: "States ratify human rights treaties after periods of regional crisis as a way to attract aid from the major international donors. . . . [P]eriods of intense regional political crisis will be followed by waves of ratification of human rights treaties." ${ }^{28}$ Signaling that they intend to remain democratic or even that they are moving towards human rights, it is argued, can result in substantial material benefits from the international community (which values indicators such as the strength of domestic institutions and human rights policies in receiving countries) through development or other assistance.

\section{THE DEBATE OVER RESERVATIONS-PARTICULARLY RESERVATIONS TO HUMAN RIGHTS TREATIES}

\section{A. Brief Introduction}

The accepted definition of a reservation is codified in Article 2(1)(d) of the Vienna Convention: it is a unilateral statement, however phrased or named, purporting to exclude or modify the legal effect of a provision(s) of a treaty in its/their application to the reserving state. However, it is the content, the limitation on the legal obligation that matters. The entering of reservations to both procedural and substantive norms of international legal instruments is now an accepted, but controversial and confusing, area of international law. The debates at the International Law Commission (ILC), the $6^{\text {th }}$ Committee of the General Assembly, and within the human rights treaty and non-treaty bodies and in academia, confirm the contentiousness of the topic. Yet it is universally acknowledged that "there is an important and legitimate

27. Lutz \& Sikkink, supra note 8 , at 5 .

28. Heather M. Smith, Explaining Ratification of Global Human Rights Instruments: The Role of Regional Instability, prepared for the Journeys in World Politics Conference, University of lowa (9-12 Mar. 2006), available at http://www.polisci.uiowa.edu/news/ workshop_papers/smith.pdf. 
role for reservations to treaties." ${ }^{\prime 29}$ Reservations enable wider participation in treaties by allowing states that would not otherwise be able to ratify. The fact that reservations are here to stay is due to the International Court of Justice's landmark Advisory Opinion on Reservations to the Genocide Convention. ${ }^{30}$ This decision, tied to the particularities of the convention and the context surrounding it, saw a move away from the previous system in which reservations were only valid if accepted by every single party to a treaty. The Advisory Opinion controversially ( $7-5$ vote) sanctioned the entering of reservations to international obligations subject to an objective test requiring such limitations to be compatible with the object and purpose of the treaty. A "State which has made and maintained a reservation which has been objected to by one or more parties to the Convention but not by others can be regarded as being a party to the Convention if the reservation is compatible with the object and purpose of the Convention." ${ }^{\prime 1}$ Behind this lies the need to create a flexible regime that can reconcile competing principles and interests-that a state can only be bound with its consent, that the unity and integrity of the treaty be preserved, and that there be widest participation possible. Whether or not perfect equilibrium is at all possible, the establishment and management of an effective and workable balanced regime of reservations was, and remains, crucial.

The Advisory Opinion permits reservations as a basic rule in order to promote treaty participation (universality), as well as to introduce the requirement of compatibility with the "object and purpose" of the treaty to preserve its integrity. An objection to a minor reservation should not result in non-ratification. Further, it enabled the other state parties to the treaty to use that test to determine if they wish to consider the reserving state a party to the treaty. The dissenting judges were highly critical of what they saw as the latter's encroachment onto sovereignty and the fundamental principle of state consent. ${ }^{32}$ Judges Higgins, Kooijmans, Elaraby, Owada, and Simma have recently underlined in their Joint Separate Opinion in the Armed Activities on the Territory of the Congo case that in 1951, the court was responding to two question put to it by the General Assembly, at a time when the Genocide Convention "stood virtually alone in the sphere of human rights" and it did not settle all matters relating to reservations (it "set out the law as to what it

29. Chairpersons of UN Human Rights Treaty Bodies, Effective Implementation of International Instruments on Human Rights, Including Reporting Obligations Under International Instruments on Human Rights, U.N. Doc. A/47/628, If 60 (10 Nov. 1992).

30. Reservations to the Convention on the Prevention and Punishment of the Crime of Genocide, 1951 I.C.J 15 (28 May) (hereafter Advisory Opinion on the Genocide Convention), available at http://teaching.law.cornell.edu/faculty/drwcasebook/docs/ genocide $\% 20$ convention $\% 20$ decision.pdf.

31. Id. at 12

32. Joint dissenting opinion of Judges Guerro, Sir Arnold McNair, Read, Hsu Mo, supra note 30 , at $13-33$. 
was asked, and no more; and did not foreclose legal developments in respect of hitherto unchartered waters in the future" $).{ }^{33}$ In time, the majority opinion was to play a critical role in coloring the ILC's work on reservations in the law of treaties, culminating in the Vienna Convention, signed in Vienna on 23 May 1969, and entered into force on 27 January 1980. ${ }^{34}$

\section{B. An Overview of the Vienna Convention Provisions on Reservations}

The Vienna Convention's reservations regime was designed to apply to all treaties, ${ }^{35}$ although in some situations returning to the pre-Advisory Opinion position (for example, Article 20(4) addresses the particular situation of treaties with a limited number of negotiating states-here, reservations are not possible). There is a strong presumption in favor of treaty participation over integrity. Edward Swaine suggests that all states may benefit from reservations because they can contribute to the depth of the treaty. Additionally, without the possibility of reservations, states would not accept a treaty with stringent terms. ${ }^{36}$ The Vienna Convention covers the formulation of reservations, acceptance, and rejection of them, legal effects, withdrawal, and formal requirements. One of the uncertainties, of which there are several, is whether they apply to all reservations or just valid ones that pass the requirements of Article 19.

33. Armed Activities on the Territory of the Congo (Democratic Republic of the Congo v. Rwanda), I.C.J (3 Feb.2006) (Judgment on Jurisdiction of the Court and Admissibility of the Application); Armed Activities on the Territory of the Congo (Democratic Republic of the Congo v. Rwanda), 2006 I.C.J (3 Feb.); Joint Separate opinion of Judge Higgins, Judge Kooijmans, Judge Elaraby, Judge Owada, and Judge Simma, 13, at 3, available at http://www.icj-cij.org/docket/files/126/10441.pdf.

34. Of the ten ASEAN states, only five: Cambodia (accession 23 May 1969), Lao PDR (accession 31 Mar. 1998), Malaysia (accession 27 July 1994), the Philippines (ratification 15 Nov. 1972) and Vietnam (accession 10 Oct. 2001) are parties. For those non-party states, many of Vienna Convention's provisions are acknowledged as reflecting custom, and the reservations provisions, being drawn from the Advisory Opinion on the Genocide Convention, are also in that category. See Introduction to the International Bill of Rights 25 (Louis Henkin ed., 1981); William A. Schabas, Reservations to the Convention on the Rights of the Child, 18 Hum. Ris. Q. 472, 481 (1996). Even the long-term outsider, the United States, has long regarded this convention as "the authoritative guide to current treaty law and practice." S. Exec. Doc. L., 92d Cong., 1st Sess., 1971, at 1; Restatement (Third) of the Foreign Relations Law of the United States (1987).

35. Report of the International Law Commission on the work of its Forty-Ninth Session, [1997], 2 Y.B. INT'L L. Comm. 60 at 9 66, U.N. Doc.A/CN.4/SER.A/1997/Add.1 (Pt. 2); containing the Preliminary Conclusions of the International Law Commission on Reservations to Normative Multilateral Treaties including Human Rights, at 92 [hereinafter ILC Preliminary Conclusions on Reservations].

36. Edward Swaine, Reserving, 31 YALE J. INT'L L. 307, 331 (2006). 
The Vienna Convention awards priority to treaty provisions that deal with reservations, with its default position being: in the absence of a specific treaty provision, a state may, when signing, ratifying, accepting, approving or acceding to a treaty, formulate a reservation. In Article 19, the Vienna Convention confirms the governing role of treaties and the consent of the parties: a treaty can prohibit any reservations, and may lay down specific requirements regarding reservations. Where a treaty is silent on reservations, then the test of the International Court of Justice re-emerges through Article 19(c), which provides that a state may, when signing, ratifying, accepting, approving or acceding to a treaty, formulate a reservation provided that the reservation is compatible with the "object and purpose" of the treaty.

One is automatically drawn to ask what the object and purpose of a treaty is. Much has been written about how vague and difficult this is to ascertain. It can sometimes be discerned from the preamble. But there is no mechanical formulation for identifying object and purpose in the Vienna Convention, (although the Special Rapporteur of the ILC is currently working on several versions of a definition) $)^{37}$ it has to be discerned on a treaty-by-treaty basis. In its Advisory Opinion on Reservations to the Genocide Convention, the International Court of Justice recognized that this treaty, as with other human rights treaties, had its own raison d'être, namely the accomplishment of those "high purposes" of the convention that constituted the "common interest" of the contracting parties..$^{38}$ This is about context. The core of the treaty, its raison d'être, is the object and purpose of a treaty, which the ILC maintains is still the most important of the criteria for determining the admissibility of reservations. ${ }^{39}$

\section{Who Decides if a Reservation is Valid or Not?}

Apart from a provision providing for a special role for competent organs of international organizations in relations to reservations to their constitutive instruments under Article 20(3), the calibration of the Vienna Convention regime allows for other states parties to object to a reservation. In other words, it is up to states parties to a treaty to object to a reservation. There is dispute over whether this concerns all reservations or just valid reservations and the effect of objecting to an invalid reservation. However, that does not mean that treaties cannot confer a power to review reservations on a court or a treaty monitoring body. ${ }^{40}$ For example, under the Genocide Convention,

37. See the different definitions proposed by the Special Rapporteur in Reservations to Treaties: Note by the Special Rapporteur on Draft Guideline 3.1.5, Definition of the Object and Purpose of the Treaty, U.N. GAOR, I.L.C., 58th Sess., U.N. Doc.A/CN.4/572, (2006).

38. Advisory Opinion on the Genocide Convention, supra note 30, at 23.

39. ILC Preliminary Conclusions on Reservations, supra note 35, at 1.

40. The controversy over treaty monitoring bodies will be examined later in this article. 
it is States who are the monitors of each other's compliance with [sic] prohibition on genocide. Article IX then gives a State who believes another State is committing genocide the chance to come to the Court. Article IX speaks not only of disputes over the interpretation and application of the Convention, but over the fulfillment of the Convention. ${ }^{41}$

It is interesting to note that in the case concerning Armed Activities on the Territory of the Congo, the International Court of Justice did not just note the Congo's failure to object to Rwanda's reservation to the Genocide Convention at the appropriate time, but it also took arguments on the issue and assessed the compatibility of Rwanda's reservation. The Court found that "it therefore does not appear contrary to the object and purpose of the Convention." 42 In its later decision on jurisdiction, the majority turned to the issue, finding that:

Rwanda's reservation to Article IX of the Genocide Convention bears on the jurisdiction of the Court, and does not affect substantive obligations relating to acts of genocide themselves under that Convention. In the circumstances of the present case, the Court cannot conclude that the reservation of Rwanda in question, which is meant to exclude a particular method of settling a dispute relating to the interpretation, application or fulfillment of the Convention, is to be regarded as being incompatible with the object and purpose of the Convention. ${ }^{43}$

In the past, objections were crucial as reservations had to be unanimously accepted. The need for objections is now less imperative in terms of state interests, but states remain the guardians of the treaty. In the "event of inadmissibility of a reservation, it is the reserving State that has the responsibility for taking action." 44 Article 20(1) lays down the basic rule that reservations to a treaty that are expressly authorized do not need to be accepted by other states unless this is a requirement of the treaty itself. Under Article 20(4), a state that enters reservations while expressing consent to be bound may only benefit from that reservation if another state accepts it. This creates a bilateral, reciprocal relationship.

The Vienna Convention shifts the balance in favor of the reserving state, for unless an objecting state is prepared to declare that there are no treaty

41. Armed Activities on the Territory of Congo, (Joint Separate Opinion), supra note 33, 9 28.

42. Armed Activities on the Territory of the Congo (New Application: 2002) (Democratic Republic of the Congo v. Rwanda), 2002 I.C.J 219 \ 72 (July 10) (Request for the Indication of Provisional Measures).

43. Armed Activities on the Territory of the Congo (Judgment on Jurisdiction of the Court and Admissibility of the Application), supra note 33, 67.

44. ILC Preliminary Conclusions on Reservations, supra note 35, ๑ 10. 
relations or the treaty is not in force between the reserving state and itself, the reserving state successfully gets its reservation. It is therefore tilted towards treaty participation rather than treaty integrity. Under Article 21(3), in a situation where a state objecting to a reservation has not opposed the entry into force of the treaty between itself and the reserving state, the provisions to which the reservation relates do not apply as between the two states to the extent of the reservation. The combined effect of a reservation and objection by another state would be to render the article inapplicable as between the two countries, but only to the extent of the reservation..$^{45}$ In other words, the reservation is given full effect in spite of the objection. It is rare that a state will oppose the entry into force of the treaty altogether but there is a clear pattern among some of the Nordic states to "sever" reservations to human rights treaties that they feel are incompatible with the object and purpose of a treaty. ${ }^{46}$ Thus, such states argue that the reservation has no legal effect and that the treaty applies in its entirety between the two states. But the Vienna Convention is silent on severance and the actual effect is unclear as reserving states do not respond.

While the standard for determining the validity of a reservation is compatibility with the object and purpose of the treaty, there is no such standard laid down for objections to Article 20. The absence of a standard for objections, and of a mechanism to ensure the objective implementation of the object and purpose test, ${ }^{47}$ has caused a doctrinal quarrel with two opposing positions: ${ }^{48}$

1. "Permissibility:" A reservation that fails the object and purpose test is invalid from the start. The restriction in Article 19(c) goes to the formulation of a reservation, stating that the formulation of such reservation is permitted only if the reservation is compatible with the

45. France-United Kingdom: Arbitration on the Delimitation of the Continental Shelf, 18 I.L.M. 397, I 61, at 419 (1979).

46. Jan Klabbers, Accepting the Unacceptable? A New Nordic Approach to Reservations to Multilateral Treaties, 69 Nordic J. INT'L L. 179, 185-86 (2000); Klabbers suggests that the Nordic states may be attempting to influence the development of the law on reservations at a time when it is under review. Id., at 191. Several examples are to be found in the objections to ASEAN state reservations which are mentioned later in this article.

47. Some treaties provide for a means of determining the validity or invalidity of a reservation. E.g., International Convention on the Elimination of All Forms of Racial Discrimination, adopted 21 Dec. 1965, 660 U.N.T.S. 195 (entered into force 4 Jan. 1969), reprinted in 5 I.L.M. 352 (1966). Under Article 20(2) of this treaty, a reservation will be deemed incompatible with its object and purpose if it is objected to by at least two-thirds of states parties. Id. However, this is an exception and it has never been used.

48. See generally Catherine Redgewell, Universality or Integrity? Some Reflections on Reservations to General Mutlilateral Treaties, 67 BRIT. Y.B. INT'L L. 245 (2004); Jean Kyongun Koh, Reservations to Multilateral Treaties: How International Legal Doctrine Reflects World Vision, 23 HaRv. INT'L L. J. 71 (1982); Derek W. Bowett, Reservations to Non-Restricted Multilateral Treaties, 48 BRITISH Y.B. INT'L L. 67 (1976-1977); J.M. Ruda, Reservations to Treaties, 146 Recuell des cours de l'Académie de Droit international de la Haye 95 (1975). 
object and purpose of the treaty. There is therefore no need to object to an impermissible reservation; it is only if a reservation is deemed "permissible" that one goes to the second tier. A state may then determine whether to accept the reservation or to object to it.

2. "Opposability:" The validity of a reservation depends on whether the other contracting state accepts it. According to this position, the object and purpose test of the Vienna Convention is not constitutive, but a "mere doctrinal assertion" that only plays an inspirational role with no legal effect. States can accept or object to reservations on a variety of grounds, such as the object and purpose test or on political, self-interested grounds. Thus, even an invalid reservation can be accepted by states.

The intentions of states in objecting or not objecting to reservations are notoriously difficult to ascertain (see below), and this doctrinal dispute remains unresolved.

\section{Consequences of an Invalid Reservation}

What are the consequences of an invalid reservation? The answer depends on whether one is inclined towards the permissibility or opposability school. This is because the Vienna Convention regime (1) does not specify the consequences of formulating an impermissible reservation under Articles 19(a) and (b); (2) does not specify the effects of formulation of a reservation that is incompatible with the object and purpose; and (3) does not specify how Article 19 relates to Article 20 on objections and acceptance of reservations. For those of the permissibility school, an invalid reservation has no legal effect; it is null and void. For the others inclined towards opposability, the consequences will depend on how other states respond, i.e., whether they accept or object to the reservation. There would be no such problem if the states that are party to a treaty expressly provide for an independent mechanism with clear authority to assess the validity of reservations and make binding findings about the consequences of invalidity.

Professor Alain Françoise Pellet takes the view that the only options for a state whose reservations are challenged on compatibility grounds are to maintain the reservation, withdraw it, replace it, or renounce being a party. ${ }^{49}$ Professor Hampson reached the same conclusion in her examination of reservations to human rights treaties for the Sub-Commission on Promotion

49. Second Report on Reservations to Treaties by Alain Pellet, Special Rapporteur, U.N. GAOR, International Law Commission, 48th Sess., I ๆ 241-51, U.N. Doc. A/CN.4/477/Add.I (1996). 
and Protection of Human Rights. ${ }^{50}$ The ILC's Special Rapporteur has proposed a Guideline (3.3.2) providing that "A reservation that does not fulfill the conditions for validity laid down in Guideline 3.1 is null and void"; the next Guideline (3.3.3) supplements this, providing that acceptance of such a reservation by another state party does not change the nullity of the invalid reservation. ${ }^{51}$ This guideline leans towards the permissibility school. For the UN Working Group on Reservations, drawn from the human rights treaty bodies, the "only foreseeable consequences of invalidity" are:

1. The state could be considered as not being a party to the treaty; or

2. The state could be considered as a party to the treaty but the provision to which the reservation has been made would not apply; or

3. The state could be considered as a party to the treaty without the benefit of the reservation.

For this working group, the consequences will depend on the intention of the state "at the time it enters its reservation. This intention must be identified during a serious examination of the available information, with the rebuttable presumption that the State would prefer to remain a party to the treaty without the benefit of the reservation, rather than being excluded." 52 This approach draws from Sir Hersch Lauterpacht's dissenting opinion in the Interhandel case, where the learned judge examined the intent of the reserving state and the significance of the reservation to its participation in the treaty. This led him to find that:

50. Specific Human Rights Issues, Reservations to Human Rights Treaties, Final Working Paper Submitted by Françoise Hampson, U.N. ESCOR, Comm'n on Hum. Rts., 56th Sess., Agenda Item 6, U.N. Doc. E/CN.4/Sub.2/2004/42 (2004) [hereinafter Hampson Final Working Paper]; For earlier reports, see also Other Specific Human Rights Issues, Reservations to Human Rights Treaties, Working Paper Preparatory to the Submission of the Expanded Working Paper by Françoise Hampson Submitted in Accordance with the Sub-Commission Decision 2002/17, U.N. ESCOR, Comm'n on Hum. Rts., 54th Sess., Agenda Item 6, U.N. Docs. E/CN.4/SUB.2/2002/34 (2002); Expanded working paper by Ms. Françoise Hampson on the question of reservations to human rights treaties, U.N. ESCOR, Comm'n on Hum. Rts., 55th Sess., Agenda letm 6, U.N. Docs. E/CN.4/ SUB.2/2003/WP.2 (2003).

51. See Text of Draft Guidelines on Reservations to Treaties Proposed in The Present Report, annexed to the Second Addendum to the Tenth Report on Reservations to Treaties by Mr. Alain Pellet, Special Rapporteur (hereinafter Text of Draft Guidelines annexed to the Second Addendum of Tenth Report by Alain Pellet), U.N. GAOR, I.L.C., 57th Sess., U.N. Doc. A/CN.4/558/Add.2 (2005).

52. Report of the Meeting of the Working Group on Reservations, International Human rights Instruments, Eighteenth Meeting of Chairpersons of the Human Rights Treaty Bodies, I 7, Recommendations of the Working Group, U.N. Doc. HRI/MC/2006/5 (2006). Some members of the Human Rights Committee have challenged this, suggesting that instead of focusing on intention, the focus should be on the presumption that the reserving state would prefer to remain a state party. See Report of the Meeting of the Working Group on Reservations, International Human Rights Instruments, Nineteenth Meeting of Chairpersons of the Human Rights Treaty Bodies, ๆ 13, U.N. Doc. HRI/MC/2007/5 (2007). 
If that reservation is an essential condition of the Acceptance in the sense that without it the declaring State would have been wholly unwilling to undertake the principal obligation, then it is not open to the Court to disregard that reservation and at the same time to hold the accepting State bound by the Declaration. ${ }^{53}$

The intent of the reserving state was considered by the European Court of Human Rights in reaching its decisions in Belilos and Loizidou, ultimately leading to the Court's severance of the offending reservations entered by Switzerland and Turkey. ${ }^{54}$ The ILC has provisionally adopted a guideline on this. ${ }^{55}$ Pellet has suggested, in discussions with the Human Rights Committee and the CERD Committee, that monitoring bodies examining reservations should conduct thorough research on the intention of the state party concerned, although this would sometimes be impossible to identify. ${ }^{56}$

\section{E. Are Human Rights Treaties an Exception to the Vienna Convention's Reservations Regime?}

The Human Rights Committee, watchdog of the International Covenant on Civil and Political Rights, argues that in the context with which it is concerned, the classical rules on reservations are:

[S]o inadequate for the Covenant, States have often not seen any legal interest in or need to object to reservations. The absence of protest by States cannot imply that a reservation is either compatible or incompatible with the object and purpose of the Covenant. Objections have been occasional, made by some States but not others, and on grounds not always specified; when an objection is made, it often does not specify a legal consequence, or sometimes even indicates that the objecting party none the less does not regard the Covenant as not in effect as between the parties concerned. In short, the pattern is so

53. Dissenting Opinion of Judge Lauterpacht, Switzerland v. United States (Interhandel case), 6 ICJ Reports 95, 117 (1959).

54. Belilos v. Switzerland, 132 Eur. Ct. H.R. (ser. A) (1988) (hereinafter Belilos); Loizidou v. Turkey (Preliminary Objections), 310 Eur. Ct. H.R. (ser. A) (1996).

55. Yearbook of the International Law Commission, Report of the Commission to the General Assembly on the Work of its Fifty-First Session, Guideline 1.3.1, U.N. Doc. A/CN.4/SER. A/1999/Add.I (Pt. 2) (1999) (method of implementation of the distinction between reservations and interpretative declarations):

To determine whether a unilateral statement formulated by a State or an international organization in respect of a treaty is a reservation or an interpretative declaration, it is appropriate to interpret the statement in good faith in accordance with the ordinary meaning to be given to its terms, in the light of the treaty to which it refers. Due regard shall be given to the intention of the State or the international organization concerned at the time the statement was formulated.

56. The Practice of Human Rights Treaty Bodies With Respect To Reservations to International Human Rights Treaties, International Human Rights Instruments, Seventeenth Meeting of Chairpersons of the Human Rights Treaty Bodies, ๆ 9 37, 38, U.N. Doc. HRI/MC/2005/5 28 (2005) [hereinafter Practice of Human Rights Treaty Bodies With Respect to Reservations to International Human Rights Treaties]. 
unclear that it is not safe to assume that a non-objecting State thinks that a particular reservation is acceptable. In the view of the Committee, because of the special characteristics of the Covenant as a human rights treaty, it is open to question what effect objections have between States inter se. However, an objection to a reservation made by States may provide some guidance to the Committee in its interpretation as to its compatibility with the object and purpose of the Covenant. ${ }^{57}$

Human rights treaties are, because of their intrusive nature, the most highly reserved category of treaties. State enthusiasm for reserving is widely recognized as the price of wide treaty participation, weakening the overall effectiveness of the norms which are, by and large, expressed as minimum standards. ${ }^{58}$ The Vienna Declaration and Programme of Action on Human Rights encouraged a restrictive approach to the use of reservations to human rights treaties, including precise and narrow formulation and compliance with the "object and purpose" rule. $^{59}$ It must be stressed that there is nothing inherently improper about making reservations to human rights treaties, for states cannot be bound without their consent. ${ }^{60}$ But compatibility with the standard that states themselves have accepted in treaty law and custom, namely compatibility with the object and purpose of the treaty, is the price asked for being different. The stakes are high. To allow states to become parties to human rights treaties despite their incompatible reservations is to dilute the standards of the protection afforded, eroding the essential functions of the treaty. Reservations can also break the unity of a human rights treaty when they sever norms that are interconnected.

Beginning his work in the area in 1994, Pellet has found that the reservations regime in the Vienna Convention "generally worked satisfactorily"

57. General Comment on Issues Relating to Reservations Made upon Ratification or Accession to the Covenant or the Optional Protocols thereto, or in Relation to Declarations Under Article 41 of the Covenant, General Comment No. 24, Human Rights Committee, If 17, U.N. Doc.CCPR/C/21/Rev.1/Add.6 (1994).

58. For more, see Rebecca J. Cook, Reservations to the Convention on the Elimination of All Forms of Discrimination Against Women, 30 VA. J. INT'L L. 643 (1990); Belinda Clark, The Vienna Convention Reservations Regime and the Convention on Discrimination Against Women, 85 AM. J. INT'L L. 281 (1991).

59. Vienna Declaration and Programme of Action, supra note 6, Pt. II, If 5.

60. It is sometimes said that there should be no reservations whatsoever to human rights treaties. It is true that the thrust in the human rights world is to work towards reservationfree treaties in "dialogue" with states, but few challenge that the making of reservations is a fundamental aspect of sovereignty, manifested through the concept that a state cannot be bound without its consent and some concessions must be made if states are to find it in their interest to enter into treaties. Even the Human Rights Committee, in its controversial General Comment No.24, General Comment on Issues Relating to Reservations Made upon Ratification or Accession to the Covenant or the Optional Protocols thereto, or in Relation to Declarations Under Article 41 of the Covenant, supra note 57, 4 , could only declare it "desirable in principle that States accept the full range of obligations because the human rights norms are the legal expression of the essential rights that every person is entitled to as a human being." 
for all treaties notwithstanding "certain ambiguities and uncertainties" and so should not be contested. ${ }^{61}$ The approach, supported by the ILC, is that the Vienna Convention regime is drawn from the Advisory Opinion on the Genocide Convention and thus sufficient account was taken of the special needs of human rights treaties. ${ }^{62}$ The Special Rapporteur and the ILC, have taken the position that there is thus no convincing basis for a special regime for reservations to human rights treaties. ${ }^{63}$ It remains open to states that are party to a treaty to include alternative provisions in treaties or to amend existing ones.

The experts in the treaty monitoring bodies and the Sub-Commission on Human Rights disagree. The controversy is in fact part of the wider debate of whether there are now "self-contained regimes" within international law and the fragmentation of the discipline. ${ }^{64}$ To this end, the ILC has specifically warned against "the proliferation of specific legal regimes on reservations that depended on the nature of the legal instruments in question, since that would lead to confusion and the fragmentation of the rules of law." ${ }^{\prime 65}$

One group argues that there needs to be a special regime for human rights treaties, while another challenges any fragmentation of international law. Some seek a better balance, pointing to problems with the existing regime. Some want universality (i.e. maximum treaty participation). Some want the integrity of the treaty preserved. This dispute also draws in the role of treaty monitoring bodies vis-à-vis reservations, with the ILC acknowledging that in the absence of an express treaty authorization they are "competent to comment upon and express recommendations with regard, inter alia, to the admissibility of reservations by States, in order to carry out the functions assigned to them." ${ }^{\prime 66}$ But that is as far as it goes-the ILC's view is that

61. Report of the International Law Commission on the Work of Its $48^{\text {th }}$ Session, ILC, 1 132, at 82, U.N. Doc.A/51/10 (1996).

62. Second Report on Reservations to Treaties by Alain Pellet, Special Rapporteur, supra note 49, ๆ $95-176$, U.N. Doc. A/CN.4/477/Add.I (1996).

63. Report of the International Law Commission on the work of its Forty-Ninth Session, 12 May-18 July 1997, Official Records of the General Assembly, U.N. GAOR, 57th Sess., Supp. 10, 75-76, U.N. Doc. A/52/10; ILC Preliminary Conclusions on Reservations, supra note 35 , ๆ $92,3$.

64. The term "self-contained regime" was coined by the Permanent Court of International Justice in the S.S. Wimbledon case and further developed in the Tehran Hostages case by the International Court of Justice. In the latter, it found that the regime of specific legal consequences contained in the Vienna Convention on Diplomatic Relations was self-contained vis-à-vis the customary international law of state responsibility. Concerning United States Diplomatic and Consular Staff in Tehran (U.S. v. Iran) 1980 I.C.J. 3, 40 (24 May 1980); see also S.S. "Wimbledon" (Britain, France, Italy \& Japan (with Poland as Intervener) v. Germany) 1923 I.C.J. 15 (17 Aug. 1923).

65. Yearbook of the International Law Commission 1997, Vol. II, Part Two, Report of the Commission to the General Assembly on the work of its Forty-Ninth Session, 1 124, U.N. Doc. A/CN.4/SER.A/1997/Add.I.

66. ILC Preliminary Conclusions on Reservations, supra note 35, ๆ 5. 
the "legal force of the findings made by monitoring bodies cannot exceed that resulting from the powers given to them for the performance of their general monitoring role . . . and in the event of inadmissibility of a reservation, it is the reserving state that has the responsibility for taking action." ${ }^{167}$ They cannot, for example, sever an invalid reservation from a treaty, unless expressly authorized to do so.

Five judges of the International Court of Justice, including Judge Higgins who was a member of the Human Rights Committee from 1984-1995, have recently waded into the debate. In their Joint Separate Opinion in the Armed Activities on the Territory of the Congo case, which exclusively concerns reservations, the five judges argued that:

The practice of such bodies is not to be viewed as "making an exception" to the law as determined in 1951 by the International Court; we take the view that it is rather a development to cover what the Court was never asked at that time, and to address new issues that have arisen subsequently. ${ }^{68}$

In their view, the current practice "is to be regarded as developing the law to meet contemporary realities, nothing in the specific findings of the Court in 1951 precluding this." 69

The ILC seems to have softened its position somewhat. In a meeting with members of the Human Rights Committee on 31 July 2003, the Special Rapporteur is reported to have "indicated that the Committee should be able to decide on the applicability and validity of reservations, and that the "severability" argument could be applied in special circumstances, but only if the monitoring body concerned proceeded to a good faith evaluation of the true intent of the reserving State."70 During a meeting with the CERD Committee on 4 August 2004, Pellet indicated that the ILC recognized that its views may have been too rigid, and would revise the preliminary conclusions, "as they could lead to some practical difficulties in cases where the reserving State did not determine the appropriate action to be taken following a declaration of invalidity of its reservations, as no mechanism obliged the State to take action." ${ }^{\prime 71}$ Pellet also suggested:

[T] hat an intermediate approach between that of the Human Rights Committee and the preliminary conclusions needed to be achieved. In his view, bodies adopting binding decisions could have the competence to take a position on the severability of reservations from the State's consent to be bound by the

67. Id. I 8 .

68. Armed Activities on the Territory of the Congo (Joint Separate Opinion), supra note 33, I 16.

69. Id. ๆ 23.

70. See Practice of the Human Rights Treaty Bodies With Respect To Reservations to International Human Rights Treaties, supra note 56, ๆ 937.

71. Id. ๆ 38 
treaty. The relevant body should, however, conduct thorough research on the intention of the State party concerned, which in some cases would be impossible to identify. ${ }^{72}$

The process of revisiting the Preliminary Conclusions has begun, ${ }^{73}$ and the Special Rapporteur has already proposed a guideline that specifically addresses reservations to general human rights treaties:

\subsubsection{Reservations to general human rights treaties}

To assess the compatibility of a reservation with the object and purpose of a general treaty for the protection of human rights, account should be taken of the indivisibility of the rights set out therein, the importance that the right which is the subject of the reservation has within the basic structure of the treaty, and the seriousness of the impact the reservation has upon it. $^{74}$

Reciprocity describes an aspect of consent. States cannot, by their reservations, limit another state's rights. The other must consent to that reservation, as it changes the legal relationship between them. Article 21 of the Vienna Convention captures this classical notion. It provides that the reservation (a) modifies for the reserving state in its relations with that other party the provisions of the treaty to which the reservation relates; and (b) modifies those provisions to the same extent for that other party in its relations with the reserving state. Acceptance (implied or express) of a reservation modifies treaty relations between the two states, in that the reservation will apply in their mutual relations. It is strictly bilateral. So while the accepting state can rely on its acceptance of the reservation with respect to the reserving state and vice versa, it cannot do so in relation to the other states that are party to the same treaty. Those other relations must be determined on a bilateral basis. What is most problematic is Article 21(3). If a state objects to a reservation but does not deny the entry into force of the treaty, then the provisions to which the reservation relates apply to those two states, but only to the extent of the reservation. Thus, the reserving state gets what it wants and it renders objection meaningless unless the objecting state is prepared to have no treaty relations whatsoever.

This leads us to the next problem-in the human rights system, reciprocal relations between one who has entered a reservation and one who has not makes no sense. Such treaties are about the assumption of obligations not in relation to other states (as per the classical treaty) but towards all individuals

72. Id .

73. See Tenth Report on Reservations to Treaties by Mr. Alain Pellet, Special Rapporteur, Addendum; U.N. GAOR, I.L.C., 57th Sess., ๆ 166, U.N.Doc. A/CN.4/558/Add.2 (2005).

74. Id., see Annex, Text of Draft Guidelines on Reservations to Treaties Proposed in the Present Report. Note that this contains no reference to the intention of the reserving state. 
within their jurisdiction. ${ }^{75}$ They are not about personal interests of states, but treaties that go towards higher values that are encapsulated in the object and purpose. That the classic rules derived from a notion of "contracts between states" cannot be easily applied in the multilateral context was recognized in the foundational Advisory Opinion on the Genocide Convention. ${ }^{76}$ The European Court of Human Rights has also recognized that reciprocity is a problematic concept for human rights treaties. ${ }^{77}$ The Inter-American Court of Human Rights has clearly expressed that while the Vienna Convention:

[R] eflects the needs of traditional multilateral instruments which have as their object the reciprocal exchange, for the mutual benefit of the States Parties, of bargained for rights and obligations ... modern human rights treaties in general, and the American Convention in particular, are not multilateral treaties of the traditional type concluded to accomplish the reciprocal exchange of rights for the mutual benefit of the contracting States. Their object and purpose is the protection of the basic rights of individual human beings. ${ }^{78}$

Since their establishment, the human rights treaty bodies have been grappling with the issue of reservations. This problem with reservations shaped the effectiveness of the treaties with which the monitoring bodies were concerned and came on top of their weak enforcement and adjudicatory powers. After initial rebuffs from the Office of Legal Affairs to initiatives by the CERD and CEDAW Committees, the treaty bodies began reviewing reservations as part of the consideration of a state's report. In the course of this, they would question state representatives about the reservations and make recommendations for withdrawal. The problems of reservations to human rights treaties came to be regularly addressed in General Comments and Concluding Observations on State Reports. But, it was soon felt that if they are to perform their mandated task of determining the extent of a state's compliance with its treaty obligations, such bodies must go further and make determinations on reservations that limit such obligations. The European Commission of Human Rights tackled its first reservation in the case of Temeltasch ${ }^{79}$ and the European Court of Human Rights severed invalid reservations in Belilos (1987) and Loizidou (1995).

75. The Effect of Reservations on the Entry into Force of the American Convention on Human Rights (arts.74 \& 45), Advisory Opinion OC-2/82, 1982 Inter-Aм. Cт. H.R. (ser. A) No. 2, ฯ 29 (24 Sept.1982).

76. Advisory Opinion on Reservations to the Genocide Convention, supra note 30, 9 $21-22$.

77. Ireland v. United Kingdom, 25 Eur. Ct. H.R. (ser. A), 239 (1978); Belilos, 132 Eur. Ct. H.R. ๆ 62.

78. The Effect of Reservations on the Entry into Force of the American Convention on Human Rights (arts.74 \& 45), Advisory Opinion OC-2/82, 1982 INTER-AM. CT. H.R. (ser. A) No. 2, ๆ $28-29$ (24 Sept.1982).

79. Temeltasch v. Switzerland, App. No. 9116/80, Eur. Comm'n H.R. 15 (5 May 1982) (Report of the Commission). 
The Human Rights Committee has been particularly forthright. In the absence of any direct authorization in the ICCPR or from the states concerned, and given the failure of the vast majority of states to exercise their right to respond to invalid reservations through objections, the committee in General Comment 24 declared itself competent to appraise and make a determination on the legal effect of reservations by states party to the ICCPR using the familiar object-and-purpose test. It took the position that the "normal consequence of an unacceptable reservation is not that the Covenant will not be in effect at all for the reserving party. Rather, such a reservation will generally be severable, in the sense that the Covenant will be operative for the reserving party without benefit of the reservation." ${ }^{\prime \prime 0}$ This sees objection as irrelevant, and its espousal of severance goes beyond permissibility. The policy reasons are clear and understandable. Functional necessity lies behind the need to tackle reservations: how else is the committee to perform its tasks if it cannot examine and assess reservations? Yet no legal grounds were relied on for this remarkable exercise of powers in a system in which decisions and recommendations of the Human Rights Committee were, and remain to this day, non-binding and unenforceable by the will of its creators. The new approach was applied for the first (and only) time in Rawle Kennedy v. Trinidad and Tobago, ${ }^{81}$ with the Committee severing the offending reservation to the Optional Protocol to the ICCPR and proceeding to hear the death-row complaint against the state, contrary to its wishes. ${ }^{82}$ This assumption of power by the Human Rights Committee and other treaty monitoring bodies has been highly controversial and directly challenged by certain states (the United States and United Kingdom), ${ }^{83}$ as well as the ILC and its Special Rapporteur, who chastised the Committee for constituting itself as the "sole judge of the permissibility of reservations." ${ }^{14}$ No other treaty body has gone as far, and there has only been that one instance of severing a reservation. The Committee has instead pursued the less confrontational approach of construing the effect of reservations narrowly rather than questioning their fundamental permissibility. It also is honoring the invocation of reservations and addressing claims directly through the use of non-reserved provisions. ${ }^{85}$

80. General Comment on Issues Relating to Reservations Made upon Ratification or Accession to the Covenant or the Optional Protocols thereto, or in Relation to Declarations Under Article 41 of the Covenant, supra note 57, 18.

81. Mr. Rawle Kennedy v. Trinidad and Tobago, Communication No. 845/1998, U.N. Doc. CCPR/C/74/D/845/1998 (2002).

82. It led to the state's withdrawal from the Optional Protocol altogether.

83. Report of the Human Rights Committee, U.N. GAOR, 50th Sess., Supp. No. 40, U.N. Doc. A/50/40, vol. I, at 127, 131 (1995).

84. Yearbook of the International Law Commission, 1997, vol. I., Summary Records of the Meetings of the Forty-Ninth Session, 12 May-18 July 1997, I 40, at 194.

85. Practice of Human Rights Treaty Bodies With Respect To Reservations to International Human Rights Treaties, supra note 56, ๆ 25, 28. 


\section{F. Ongoing Work on Reservations}

Since its forty-sixth session in 1994, the ILC has been working on the "law and practice relating to reservations to treaties," which is now re-classified as "reservations to treaties." ${ }^{86}$ Its original focus was the permissibility versus opposability doctrinal debate. Having decided that there is no need to change the reservations regime, the ILC is now working on draft guidelines that are intended to eventually serve as a Guide to Practice for states when making reservations to treaties. ${ }^{87}$ Records of the discussions on the ILC and in the sixth Committee of the General Assembly reveal strongly divergent positions, ${ }^{88}$ although the ILC was still able to adopt Preliminary Conclusions as early as 1997 at its forty-ninth session.

On the human rights side of the United Nations, the treaty monitoring bodies are carrying on as usual. ${ }^{89}$ The Human Rights Committee continues to endorse General Comment 24, although it has not developed its practice of severing reservations, and its review of the recent periodic report of the United States, suggests a less forceful approach is being employed with respect to reservations.$^{90}$ Its general assertiveness is not followed by committees such as that on the Rights of the Child, whose concerns are more with not detracting from the universality of the Convention on the Rights of the Child. ${ }^{91}$ Reservations are not of particular significance for the Committees against Torture, Economic Social and Cultural Rights, and Migrant Workers. But efforts are well underway on harmonizing the work of the treaty bodies

86. The title change was proposed by the Special Rapportuer and accepted by the members of the commission in its 1995 session, see the Yearbook of the International Law Commission, Vol. II U.N. Doc, A/CN.4/SER.A/1995/Add.I (Pt. 2), I 434, at 103 (1995).

87. Report of the International Law Commission Fifty-Fifth Session General Assembly Official Records, Fifty-Eighth Session, Supplement No. 10 (A/58/10), Text of the draft guidelines on reservations to treaties provisionally adopted so far by the Commission, U.N. Doc. A/CN.4/L.609/Add.2 (2001).

88. See for example, the Report of the International Law Commission on the work of its Forty-Ninth Session, supra note 35, ๆ 9 92-156; Press Release GA/L/3055, Assembly's Legal Committee is told Law Commission should set up system to judge reservations to multilateral treaties, 5 Nov. 1997; Press Release GA/L/3307, Legal Committee hears call for meeting of Human Rights Experts on Issue of States Wishing to Enter Reservations to Treaties, 31 Oct. 2006.

89. For overview of the practice in the treaty bodies, see the numerous reports emerging from Professor Françoise Hampson's comprehensive study on reservations to human rights treaties. Hampson Final Working Paper, supra note 50; Practice of Human Rights Treaty Bodies With Respect To Reservations to International Human Rights Treaties supra note 56 , at 56 .

90. Consideration of Reports Submitted By States Parties Under Article 40 of the Covenant, Concluding observations of the Human Rights Committee, International Covenant on Civil and Political Rights, Human Rights Committee, 87th Sess., I 6, U.N. Doc. CCPR/ C/USA/CO/3/Rev.1 (2006).

91. Practice of Human Rights Treaty Bodies With Respect To Reservations to International Human Rights Treaties, supra note 56, ๆ 12. 
and developing a common approach to reservations through an inter-committee Working Group on Reservations chaired by Sir Nigel Rodley. ${ }^{92} \mathrm{~A}$ joint General Comment on Reservations is planned. Recommendations have been made to the Chairpersons of the human rights bodies, who have already issued harmonized guidelines on reporting of reservations, requiring reserving states to explain the scope of their reservations, the reason why they are considered necessary and have been maintained, their precise effect in terms of national law and policy, consistency with other treaty obligations, and plans to limit or withdraw them..$^{93}$ These developments follow on from the important work done for the United Nations Sub-Commission on Promotion and Protection of Human Rights by Professor Françoise Hampson, examining the actual reservations and interpretative declarations made to human rights treaties in light of the legal regime applicable to reservations and interpretative declarations. Human rights treaty bodies "should be encouraged to continue their current practice of entering a dialogue with reserving States, with a view to effecting such changes in the incompatible reservation as to make it compatible with the treaty." ${ }^{\prime 4}$ In her final report, she found that drawing from the normal rules of treaty law and the principle that a judicial or quasi-judicial body had the authority to determine whether or not it had jurisdiction, the human rights treaty bodies had the competence to determine whether or not a reservation was incompatible with the object and purpose of the treaty. ${ }^{95}$ The project is likely to be revived when the ILC and its rapporteur examine the validity of reservations and their consequences.

Despite their differences, the ILC and the United Nations human rights bodies are in a dialogue that began with comments by the Chairpersons of Human Rights Treaty Bodies on the ILC's preliminary conclusions. ${ }^{96}$ Such exchanges have been expressly encouraged by the Sixth Committee of the General Assembly; the next meeting was planned for May 2007 when

92. Report of the Meeting of the Working Group on Reservations, International Human Rights Instruments, Nineteenth Meeting of Chairpersons of the Human Rights Treaty Bodies, I 12, 16, U.N. Doc. HRI/MC/2007/5/ (2007); Report of the Meeting of the Working Group on Reservations, International Human Rights Instruments, U.N. Doc. HRI/MC/2007/5 (2007).

93. Harmonized Guidelines on Reporting Under the International Human Rights Treaties, Including Guidelines on a Common Core Document and Treaty-Specific Targeted Documents, Report of the Secretariat, International Human Rights Instruments, ๆ 45, U.N. Doc. HRI/MC/2005/3 (2005).

94. Hampson Final Working Paper, supra note 50, at 19.

95. Hampson Final Working Paper, supra note 50, ब 71.

96. In a 1998 letter to the ILC, the Chairpersons of the Human Rights Treaty Bodies argued that the preliminary conclusions did not accord sufficient attention to the fact that human rights treaties, by virtue of their subject matter and their role, could not be placed on precisely the same footing as other treaties with different characteristics; see also Press Release, Committee On Elimination Of Racial Discrimination Discusses Reservations By States Parties To Human Rights Treaties (3 Aug. 2004) (on file with the author); Hampson Final Working Paper, supra note 50, ๆ ๆ 63, 64. 
the ILC next meets. ${ }^{97}$ The protracted debate cannot go on for much longer in this manner. The Special Rapporteur has been working on the issue of reservations since 1994, producing yearly reports of great complexity and length, and there have been calls for the matter to be concluded by the ILC's next session.

\section{ASEAN STATES RESERVATIONS TO CEDAW AND CRC}

\section{A. Methodology ${ }^{98}$}

This study includes assessment of all objections against substantive (normative) reservations filed by parties to a treaty. Within "objections" are included not just objections that the Depository has registered as objections, but also objections registered by the Depositary as communications for being filed after the end of the twelve month period specified in Article 20(5) of the Vienna Convention (the UNTS record separates out objections and communications, which are dealt with in the Notes section). This approach has been adopted because including the communications allows a more complete picture of how other states view the ASEAN reservations. They are also included in light of the fact that the legal effect of such challenges to the reservation is still unresolved (the Depositary's practice is that it is for states to determine the status of such objections ${ }^{99}$ although they are circulated as communications) and because many of the objecting states have categorically stated their understanding that the twelve month time limit in Article 20(5) does not apply to invalid reservations, specifically the ones they are objecting to. For example, in relation to Malaysia's CRC reservations, both Belgium and Denmark specifically stated that they made those objections on the understanding that the twelve month rule is inapplicable to invalid reservations. These states clearly regard their challenges as objections, with legal effect.

There are also a number of conditional statements limiting the state's obligations, but rather than being termed reservations are in fact called

97. Press Release, U.N. GAOR, Legal Committee Hears Call for Meeting of Human Rights Experts on Issue of States Wishing to Enter Reservations to Treaties (31 Oct. 2006), GA/L/3307.

98. Data about ASEAN states and their reservations to CEDAW, CRC and its two protocols, and objections thereto, was taken from the United Nations Treaty Collection, available at http://www.bayefsky.com.

99. The Chief of the Treaty Section argues there should be no legal consequences. See Summary of Practice of the Secretary-General as Depositary of Multilateral Treaties, United Nations Treaty Collection, I 213; Palitha T.B. Kohona, Reservations: Discussion of Recent Developments in the Practice of the Secretary-General of the United Nations as Depositary of Multilateral Treaties, 33 GA J. INT'L \& Comp. L. 415, 445 (2004-2005). 
"declarations." International law is concerned about the content of the statement, rather than its label, in determining whether it is a reservation or not. Under Article 2(1)(d) of the Vienna Convention, the term reservation means a unilateral statement however it is described (i.e. it is the substance that counts), made by a state, when signing, ratifying, accepting, approving or acceding to a treaty and not at a later stage; and whereby it purports to exclude or to modify the legal effect of certain provisions of the treaty in their application to that state. An interpretative declaration that seeks to limit a state party's obligations under the instrument will be a reservation and subject to the rules on regulations in international law. ${ }^{100}$ Examples of this are Singapore's declarations to CRC, which this article includes as a reservation. ${ }^{101}$

The assessment of the objections is made in full awareness of their weaknesses as a barometer of state practice. States object and fail to object for many different reasons, some are principled and others are not. There is undeniably a lack of consistency in objections-a state may object to one reservation, but not to an identically worded reservation from another country. Some states may not have objected because of their belief that they need not object to invalid reservations. Others may not have seen it in their interests to do so. Some may have wanted to but declined to do so for fear of it being seen as an unfriendly act. Yet more may simply not have had time or the wherewithal to do so. Some may be driven by political motivations to object. There are of course other reasons for objecting to reservations that are not provided here.

This article examines the objections with an awareness of all these factors. However, while we cannot presume the intentions of states who do not object, and we cannot know if there are ulterior motives for objecting, we do at least have those objections which provide much material for analysis. States, as we know, do not lightly engage in making objections, which are not the friendliest action to undertake in international relations. Therefore, while caution is to be exercised, these often well-argued objections warrant careful consideration.

100. Belilos, 132 Eur. Ct. H.R. ฯ 49.

101. (1) The Republic of Singapore considers that a child's rights as defined in the Convention, in particular the rights defined in article 12 to 17, shall in accordance with articles 3 and 5 be exercised with respect for the authority of parents, schools and other persons who are entrusted with the care of the child and in the best interests of the child and in accordance with the customs, values and religions of Singapore's multi-racial and multi-religious society regarding the place of the child within and outside the family. (2) The Republic of Singapore considers that articles 19 and 37 of the Convention do not prohibit (a) the application of any prevailing measures prescribed by law for maintaining law and order in the Republic of Singapore; (b) measures and restrictions which are prescribed by law and which are necessary in the interests of national security, public safety, public order, the protection of public health or the protection of the rights and freedoms of others; or (c) the judicious application of corporal punishment in the best interest of the child.

Singapore's Reservation, supra note 22. 


\section{B. CEDAW}

The object and purpose of CEDAW is to promote and achieve the elimination of all forms of discrimination against women. All ASEAN states are party to CEDAW, which has 185 parties. Article 28 permits reservations to be made. While there is no formal requirement of acceptance by other states, they must not be incompatible with the object and purpose of the Convention. Belinda Clark points out that the article dealing with reservations in CEDAW is not identical to the Vienna Convention, and it is not clear why the words "may not be formulated" have been replaced with "shall not be permitted." 102 That aside, the setup reflects the flexible regime laid down in the Vienna Convention, under which it is ultimately states which decide whether a reservation is valid or not. CEDAW is silent on the legal effect of reservations, and provides for no mechanism whereby there can be an objective determination of whether a reservation is in fact valid.

The CEDAW Committee has adopted general and specific comments on the many reservations that have been entered to this treaty. ${ }^{103}$ The Committee has expressed "concern in relation to the significant number of reservations that appeared to be incompatible with the object and purpose of the Convention" and suggested "that all States parties concerned reconsider such reservations with a view to withdrawing them." ${ }^{104}$ In 1998, it adopted a statement stressing that Articles 2 and 16 were core provisions of the Convention. ${ }^{105}$ Article 2 is central to the objects and purposes of the convention and sets out the strategies by which discrimination against women is to be eliminated. Article 2(f) sets out the obligation to modify and abolish laws, regulations, customs and practices discriminating against women. By entering reservations to that provision, states may effectively exempt themselves from responding to both the causes and the manifestations of all forms of violence against women. Reservations to Article 2(g) (national penal provisions discriminating against women) permit states to take little or no action to amend laws which lead to de jure or de facto discrimination against women. These include laws that criminalize sexual relationships outside marriage, or laws that impose restrictions on dress codes or restrictions on the freedom of movement. It also includes laws that do not provide for adequate or any penalties for violence against women, including rape, and

102. Belinda Clark, The Vienna Convention Reservations Regime and the Convention on Discrimination Against Women, 85 AM J. INT'L L. 281, 307 (1991).

103. CEDAW General Recommendation No.4 (6 $6^{\text {th }}$ sess. 1987); CEDAW General Recommendation No.20 ( $11^{\text {th }}$ sess. 1992); CEDAW General Recommendation No. 21: Equality in Marriage and Family Relations ( $13^{\text {th }}$ sess. 1994); CEDAW General Recommendation No. $23\left(16^{\text {th }}\right.$ sess. 1997).

104. CEDAW General Recommendation No. 4, Id., pmble.

105. Report of the Committee on the Elimination of Discrimination against Women, U.N. Doc. A/53/38/Rev.1, Ch. 1, ๆ 6 (1998). 
the so called "honor killings." Reservations to Article 16, whether lodged for national, traditional, religious or cultural reasons, are incompatible with the convention and thus impermissible. In General Comment 21, the Committee stated that

Many of these countries [which have entered reservations to Article 16] hold a belief in the patriarchal structure of a family which places a father, husband or son in a favourable position. In some countries where fundamentalist or other extremist views or economic hardships have encouraged a return to old values and traditions, women's place in the family has deteriorated sharply. In others, where it has been recognized that a modern society depends for its economic advance and for the general good of the community on involving all adults equally, regardless of gender, these taboos and reactionary or extremist ideas have progressively been discouraged. ... [T] he Committee requires that all States parties gradually progress to a stage where, by its resolute discouragement of notions of the inequality of women in the home, each country will withdraw its reservation, in particular to articles 9, 15 and 16 of the Convention. States parties should resolutely discourage any notions of inequality of women and men which are affirmed by laws, or by religious or private law or by custom, and progress to the stage where reservations, particularly to article 16 , will be withdrawn. ${ }^{106}$

In light of Article 28(2) and the test of compatibility with the object and purpose of the Convention, it referred to the many reservations which represent a serious problem for the implementation of the Convention and the Committee's ability to monitor compliance with it.

The CEDAW Committee regularly raises the issue of reservations with states in the course of the state reporting process. Very active in tackling reservations, this Committee has assumed the authority to consider and make findings about reservations being incompatible with the object and purpose of the treaty (e.g., in relation to Brunei Darussalam, Malaysia, and Singapore), but it has not severed any reservations which it finds contrary to Article 51 of the Convention.

\section{ASEAN States' Reservations to CEDAW}

There are five ASEAN states that have either not entered reservations to CEDAW or have withdrawn all their reservations. These are Cambodia, Indonesia, Lao PDR, the Philippines, and Vietnam. Myanmar's only reservation relates to Article 29(1) on dispute settlement before the ICJ, a provision to which reservations are expressly permitted.

The remaining states-Brunei Darussalam, Malaysia, Singapore, and Thailand-have entered reservations to six substantive (i.e., normative) provisions, including some which are to provisions that the CEDAW Committee considers essential (e.g., Articles 2 and 16).

106. CEDAW General Recommendation No. 21, supra note 103, ๆ 42-44. 
Article 2-Policy Measures

Article 5(a)-Role Stereotyping and Prejudice

Article 7(b)_-Political and Public Life

Article 9(2)—Nationality

Article 11-Employment

Article 16-Marriage and Family Life
Singapore

Malaysia

Malaysia

Malaysia, Brunei, Singapore

Malaysia, Singapore

Singapore, Thailand, Malaysia (Arts. 16(1)(a), (c), (e), (f), (g) and 16(2)).

In addition to these article-specific reservations, these ASEAN states have also made reservations of a general nature, with potential impact on all provisions of the treaty.

\section{RESERVING STATE}

Brunei Darussalam

Malaysia

\section{RESERVATION CATEGORY}

Constitution, Islam ${ }^{107}$

Shariah, Constitution ${ }^{108}$

107. The Government of Brunei Darussalam expresses its reservations regarding those provisions of the said Convention that may be contrary to the Constitution of Brunei Darussalam and to the beliefs and principles of Islam, the official religion of Brunei Darussalam and, without prejudice to the generality of the said reservations, expresses its reservations regarding paragraph 2 of Article 9 and paragraph 1 of Article 29 of the Convention.

Reservation to CEDAW, Brunei Darussalam, available at http://www2.ohchr.org/english/ bodies/ratification/8.htm.

108. The original reservations read as follows:

The Government of Malaysia declares that Malaysia's accession is subject to the understanding that the provisions of the Convention do not conflict with the provisions of the Islamic Sharia' law and the Federal Constitution of Malaysia. With regards thereto, further, the Government of Malaysia does not consider itself bound by the provisions of articles 2 (f), 5 (a), 7 (b), 9 and 16 of the aforesaid Convention. In relation to article 11, Malaysia interprets the provisions of this article as a reference to the prohibition of discrimination on the basis of equality between men and women only.

On 6 February 1998, the Government of Malaysia notified the Secretary-General of a partial withdrawal as follows:

1. ... 2. With respect to article 5 (a) of the Convention, the Government of Malaysia declares that the provision is subject to the Syariah law on the division of inherited property.

3. With respect to article 7 (b) of the Convention, the Government of Malaysia declares that the application of said article 7 (b) shall not affect appointment to certain public offices like the Mufti Syariah Court Judges, and the Imam which is in accordance with the provisions of the Islamic Shariah law.

4. With respect to article 9, paragraph2 of the Convention, the Government of Malaysia declares that its reservation will be reviewed if the Government amends the relevant law.

5. With respect to article 16.1 (a) and paragraph 2, the Government of Malaysia declares that under the Syariah law and the laws of Malaysia the age limit for marriage for women is sixteen and men is eighteen.

The Government of Malaysia withdraws its reservation in respect of article 2(f), 9(1), 16(b), 16(d), 16(e) and 16(h)."

Reservation to CEDAW, Malaysia, available at http://www2.ohchr.org/english/bodies/ ratification/8.htm. 
Singapore

Private/religious/personal laws, socio-political

Thailand conditions, national legislation ${ }^{109}$

Constitution, national laws ${ }^{110}$

The effect of these catch-all reservations is to allow each of these states a fall-back whenever they do not wish to comply with a CEDAW obligation to amend laws or practices that are incompatible.

\title{
2. Objections by other States
}

\author{
The objections to reservations entered to CEDAW by the ASEAN states have \\ been made by Europe, and Mexico.
}

109. (1) In the context of Singapore 's multi-racial and multi-religious society and the need to respect the freedom of minorities to practise their religious and personal laws, the Republic of Singapore reserves the right not to apply the provisions of articles 2 and 16 where compliance with these provisions would be contrary to their religious or personal laws. (2) Singapore is geographically one of the smallest independent countries in the world and one of the most densely populated. The Republic of Singapore accordingly reserves the right to apply such laws and conditions governing the entry into, stay in, employment of and departure from its territory of those who do not have the right under the laws of Singapore to enter and remain indefinitely in Singapore and to the conferment, acquisitions and loss of citizenship of women who have acquired such citizenship by marriage and of children born outside Singapore. (3) Singapore interprets article 11, paragraph 1 in the light of the provisions of article 4, paragraph 2 as not precluding prohibitions, restrictions or conditions on the employment of women in certain areas, or on work done by them where this is considered necessary or desirable to protect the health and safety of women or the human foetus, including such prohibitions, restrictions or conditions imposed in consequence of other international obligations of Singapore and considers that legislation in respect of article 11 is unnecessary for the minority of women who do not fall within the ambit of Singapore's employment legislation. (4) The Republic of Singapore declares, in pursuance of article 29, paragraph 2 of the Convention that it will not be bound by the provisions of article 29, paragraph 1.

Reservation to CEDAW, Singapore, available at http://www2.ohchr.org/english/bodies/ ratification/8_1.htm.

110. 1. In all matters which concern national security, maintenance of public order and service or employment in the military or paramilitary forces, the Royal Thai Government reserves its right to apply the provisions of the Convention on the Elimination of all Forms of discrimination against Women, in particular articles 7 and 10 , only within the limits established by national laws regulations and practices. 2. With regard to article 9, paragraph 2, [ . . . ] the Royal Thai Government considers that the application of the said provisions shall be subject to the limits and criteria established by national law, regulations and practices. 3. The Royal Thai Government does not consider itself bound by the provisions of [ . . . ] article 16 and article 29, paragraph 1, of the Convention.

On 25 January 1991, the Government of Thailand notified the Secretary-General of its decision to withdraw the reservations made upon accession to the extent that they apply to Article 11, I 1 (b), Article 15, I 3. Subsequently, on 26 October 1992, the government of Thailand notified the Secretary-General of its decision to withdraw one of the reservations made upon accession to the Convention, i.e., that relating to Article 9 (2), which reservation reads as follows:

2. With regard to article 9, paragraph 2, [ . . ] the Royal Thai Government considers that the application of the said provisions shall be subject to the limits and criteria established by national law, regulations and practices." Subsequently, on 1 August 1996, the Government of Thailand notified the Secretary-General of its decision to withdraw, as from that same date, the following reservation, made upon accession: "

1. In all matters which concern national security, maintenance of public order and service or employment in the military or para military forces, the Royal Thai Government reserves its right to apply the provisions of the Convention on the Elimination of all Forms of Discrimination against Women, in particular articles 7 and 10, only within the limits established by national laws, regulations and practices.

Reservations to CEDAW, Thailand, available at http://www.unhchr.ch/html/menu3/b/ treaty9_asp.htm, see also note 50 . 
Brunei Darussalam

Brunei Darus

$\begin{array}{ll}\text { Denmark } & \\ \text { Estonia } & \text { Germany } \\ & \text { Ireland } \\ & \text { Latvia } \\ \text { Malaysia } & \text { Finland }\end{array}$

Germany

Netherlands

Norway

Denmark

France $^{111}$

Singapore Finland

Netherlands

Norway

Denmark

Sweden
Vagueness or imprecision Incompatible with the object and purpose of the treaty

Vagueness or imprecision Incompatible with the object and purpose of the treaty Vagueness or imprecision Incompatible with the object and purpose of the treaty Vagueness or imprecision Incompatible with the object and purpose of the treaty Vagueness or imprecision Incompatible with the object and purpose of the treaty Incompatible with the object and purpose of the treaty Vagueness or imprecision Invocation of domestic law Incompatible with the object and purpose of the treaty Incompatible with the object and purpose of the treaty Invocation of domestic law Incompatible with the object and purpose of the treaty Invocation of domestic law Invocation of religious law Incompatible with the object and purpose of the treaty Invocation of internal law Incompatible with the object and purpose of the treaty (Reservations to Articles 2(f), 5(a), 9 and 16) Incompatible with the object and purpose of the treaty Vagueness or imprecision Too wide Invocation of domestic law Incompatible with the object and purpose of the treaty Incompatible with the object and purpose of the treaty ( $1^{\text {st }}$ reservation) Invocation of domestic law (2nd reservation) Invocation of domestic law Invocation of domestic law Incompatible with the object and purpose of the treaty Vagueness or imprecision

111. This objection relates to the partial withdrawal and modifications made by Malaysia on 6 Feb. 1998. 
Thailand

Thailand Germany
Sweden
Mexico
Netherlands

Too wide

Incompatible with object and purpose Incompatible with the object and purpose of the treaty

Incompatible with the object and purpose of the treaty

Incompatible with the object and purpose of the treaty

Every one of the six states objecting to Brunei Darussalam's reservations did so on the grounds that they were incompatible with the object and purpose of CEDAW. Germany pointed out that the general reservation left the extent of Brunei's obligations unclear and as such it was incompatible with the object and purpose of the treaty, and the specific reservation to Article 9(2) would discriminate against women, which would also be incompatible with the object and purpose of the treaty. Denmark pointed out that the reservation to Article 9(2) would discriminate against women, and thus was contrary to the object and purpose of CEDAW, and "accordingly inadmissible and without effect under international law." ${ }^{\prime 12}$ It called on Brunei Darussalam to reconsider its reservations. Estonia objected to Article $9(2)$ and the general reservation as being incompatible with the object and purpose. Ireland was more nuanced about the general reservation casting doubts on Brunei Darussalam's commitment, but was clear that the Article 9(2) reservation was incompatible with the object and purpose of the treaty. Austria also had doubts about the commitment of Brunei Darussalam to its treaty obligations, and pointed out that states are expected to be prepared to undertake legislative changes to meet their treaty obligations. Only Latvia, which pointed out that the distinction between genders in relation to nationality of children was contrary to equality between men and women, and thus contrary to the object and purpose of CEDAW, severed the reservations. For the rest the treaty applied subject to the reservation.

Each of the six states objecting to Malaysia's reservations found them to be contrary to the object and purpose of CEDAW. Finland declared that the reservations to Articles $2(\mathrm{f})$ and $5(\mathrm{a})$ concerned two fundamental provisions of the Convention the implementation of which is essential to fulfilling its object and purpose. Denmark declared that the reservations covered central provisions of the treaty. Both these states severed the reservations-Finland finding them to be devoid of legal effect, and Denmark declared them without effect under international law. No state opposed the treaty's entry into force between itself and Malaysia.

112. Denmark's comments with regard to the reservations made by Brunei Darussalam upon accession to CEDAW, (6 OCT. 2006), available at http://www2.ohchr.org/english/bodies/ratification/8_1.htm 
Of the five states that objected to Singapore's reservations, three were clear that they were incompatible with the object and purpose of CEDAW, and two used softer language about how the reservations "may create doubts" or "creates doubts" about Singapore's commitment to the object and purpose of the convention. ${ }^{113}$ Finland declared that the reservations to Articles $2(f)$ and 5(a) concerned two fundamental provisions of the Convention, the implementation of which is essential to fulfilling its object and purpose. Denmark pointed out the reservations covered central provisions of the Convention. These two states, along with Sweden, severed the reservations. No state opposed the treaty's entry into force between itself and Singapore.

Every one of the four states who objected to Thailand's reservation found it to be contrary to the object and purpose of CEDAW. Sweden took the position that the reservations:

[I]f put into practice, would inevitably result in discrimination against women on the basis of sex, which is contrary to everything the Convention stands for. It should also be borne in mind that the principles of the equal rights of men and women and of non-discrimination on the basis of sex are set forth in the Charter of the United Nations as one of its purposes, in the Universal Declaration of Human Rights of 1948 and in various multilateral instruments, to which Thailand [is a party]. ${ }^{114}$

Mexico pointed out that Thailand had accepted the non-discrimination provisions in the ICCPR, ICESCR, and also the UDHR, and that it was inconsistent with its contractual obligations to claim reservations on these matters in CEDAW. None of the objecting states severed the reservation; none of them opposed the treaty's entry into force between themselves and Thailand. None of the reserving states responded to the objections.

\section{ASEAN States: Their reservations and the CEDAW Committee}

Malaysia's combined initial and second periodic report was examined by the CEDAW Committee on 24 May 2006. ${ }^{115}$ The report noted that Malaysia had ratified the convention with a number of reservations because some articles

113. In its Advisory Opinion on Reservations to the Genocide Convention, supra note 30, the majority did point out that states may object to reservations without claiming they are incompatible with its object and purpose; in such cases the treaty remains in force between the reserving and objecting States without the clauses affected by the reservation. Id., at 27.

114. Sweden's comment on Thailand's reservations to CEDAW, (17 Mar. 1986), available at http://www2.ohchr.org/english/bodies/ratification/8_1.htm

115. Combined Initial and Second Periodic Reports of States Parties: Malaysia, U.N. Doc. CEDAW/C/MYS/1-2 (12 Apr. 2004). The précis of the discussions between the state and the Committee are drawn from Malaysia Needs New Laws Aimed Specifically at Ending Discrimination on Basis of Sex, Gender, Say Committee's Expert Members, U.N. Doc. WOM/1562 (24 May 2006). 
were deemed contradictory to the county's laws. Malaysia explained that an Inter-Ministry Committee had been set up to review reservations to Article 5 (a) and 7(b) and the consultations with different governmental departments and agencies was underway. It explained that it was considering withdrawing the reservations to these two provisions, but not the others. Committee member Ms. Schopp-Schilling specifically urged Malaysia to withdraw its reservation to Article 16 on marriage and family life without delay. Malaysia explained that in relation to the Article $7(\mathrm{~b})$ reservation, some posts in the Shariah court could not be held by women as these were religious offices involving leading people in prayer, which according to Islamic rules women were not always allowed to do. Committee member Ms. Belmihoub-Zerdani took issue with the reservation to Article 9(2), saying it was the most flagrant example of discrimination to prohibit a woman married to a foreigner from transferring her nationality to her own children, even when there were no religious obstacles to doing so under Muslim law. Malaysia also explained that family laws were so entrenched in Malaysia that the belief was that Shariah law actually offered women greater protections than non-Islamic law. The issue was not that Malaysia had taken a step back but that there were certain ambiguities, which was why the government had undertaken a review. In its concluding observations on 31 May 2006, the CEDAW Committee commended Malaysia for withdrawing reservations and considering withdrawal of reservations to Articles 5(a) and 7(b) but expressed concern at its unwillingness to withdraw the rest. It was particularly concerned at the state's position that laws based on Shariah interpretation cannot be reformed. Malaysia was urged to "review all its remaining reservations with a view to withdrawing them, and especially reservations to Article 16, which are contrary to the object and purpose of the Convention."116

Singapore's initial and second periodic reports to the CEDAW Committee were considered on 9 July $2001 .{ }^{117}$ In this meeting, the state was pressed about its reservations. It responded that Singaporean society was dynamic and existed in an international context, as did its laws and policies. Singapore had to be mindful that its laws reflect its economic, social, and geo-political situation, its constraints and realities, as well as the kind of society Singa-

116. Concluding Comments on the Elimination of Discrimination against Women: Malaysia, U.N. Doc. CEDAW/C/MYS/CO/2, I 10 (31 May 2006).

117. Initial Report of States Parties: Singapore, U.N. Doc. CEDAW/C/SGP/1 (18 Jan. 2000); Second Periodic Report of States Parties: Singapore, U.N. Doc. CEDAW/ C/SGP/2 (3 May 2001). The Committee considered the reports at its $514^{\text {th }}, 515^{\text {th }}$, and $522^{\text {nd }}$ meetings, on 9 and 13 July 2001. The précis of discussions between the state and the Committee is drawn from the record of proceedings in Singapore Delegates, Describing Compliance With Women's Convention, Say Account Must Be Taken Of Cultural Tradition, Need for Stability: Committee Chairperson Says Concern Remains Over 'Reservations' Which Contradict Letter and Spirit of International Agreement, U.N. Doc. WOM/1293 (13 Jul. 2001). 
poreans wanted for themselves and their children. Singapore was serious about advancing the de facto status of its women and their equality with men, and it was in that spirit that it had ratified the Convention. It also had to be sensitive to the different cultural and religious beliefs of its people, as they were the foundation of the country's social and political stability. It was committed to the advancement of the status of women and to ensuring that the objectives of the Convention were upheld and advanced. While it may not be possible to fully comply with the obligations under the Convention, it had been Singapore's choice to accede to the Convention, as it believed its reservations would allow it to do so. The state's position was that reservations to Articles 2 and 16 were necessary, because the Constitution of Singapore required respect for cultural and national peculiarities of various groups of society. It was important to maintain the delicate balance in Singapore's multicultural society. There were provisions in the Administration of Muslim Law Act, which may not be consistent with the Convention (for instance, the right of a Muslim to marry up to four wives). Singapore had considered the views of Islamic authorities when making the reservations. On the Article 9 reservations, it was stressed that Singapore was not the only country that adopted laws to govern employment, stay, and departure of people to its territory. Such requirements were dependent upon each country's unique needs and were gender-neutral. The reservation to Article 9 was also required in light of Singapore's Constitution, which allowed for citizenship by descent on the children born overseas of a Singaporean father. There were no similar provisions regarding the children born from Singaporean mothers abroad. The matter would continue to be discussed in the Parliament, in view of the changing social values and realities. The reservations to Article 11 were necessary in order to safeguard the welfare of women and their unborn children from certain hazardous occupations and in line with the reference to the obligations of state parties to safeguard the functions of reproduction. That was necessary in light of the country's small population and low fertility rate. For that reason, for example, women were excluded from certain hazardous occupations in the military to avoid deploying them in combat roles in time of hostility. In its Concluding Observations, the CEDAW Committee expressed "deep concern regarding the reservations made by the government of Singapore to Articles 2, 9, 11, paragraph 1, and 16 of the Convention.... [A]rticles 2 and 16 are the very essence of obligations under the Convention."118 It urged Singapore to continue the process of reform of Muslim personal law in consultation with members of different ethnic and religious groups, including women.

118. Report of the Committee on the Elimination of Discrimination against Women $\left(24^{\text {th }}\right.$ and $25^{\text {th }}$ Sess. 2001), U.N. GAOR, 56 ${ }^{\text {th }}$ Sess., Supp. No.38, I 73, 74, U.N. Doc. A/56/38 (2001). 
Thailand's first report was considered in 1990, and by the time its fourth and fifth periodic reports were jointly examined on 20 January 2006, had only two out of its original seven reservations remaining (Articles 16 and 29(1))..$^{119}$ In its 1999 discussions with the Committee, Thailand explained the social resistance to Article 16 on the elimination of discrimination in marriage and family life. The state explained that Thai men had strongly opposed attempts made by the National Commission on Women's Affairs to amend laws to facilitate the withdrawal of the reservation to Article 16 . Its proposals had been rejected by the Council of State. In its most recent report, Thailand stated that despite the removal of the reservation to Article $16(\mathrm{~g})$ (rights in marriage, for example to choose the family name, profession, and occupation) in 2003, there were still a number of provisions in its family law that could be seen as discriminatory under CEDAW. This was being discussed. The government was "doing its utmost to bring the country's Family Law in line with Article 16 of the Convention, while ensuring that the adopted measures did not undermine the richness of Thailand's cultures and traditions." 120 In replying to further questions on reservations, the delegation assured the committee that efforts were underway to persuade the government to withdraw its reservation to all points under marriage and family, but there were sticking points on divorce and compensation in the breach of an engagement contract. Committee Expert Dubravka Simonovic was critical saying it was her impression that the Convention was perceived as a Declaration rather than as a binding agreement. The state assured the Committee that it respected the binding nature of CEDAW, but individuals might not perceive it that way. In its Concluding Observations, the CEDAW Committee underlined its concern "that the State party continues to retain its reservation to Article 16 of the Convention. The Committee draws the attention of the State party to the fact that reservations to Article 16 [of the convention] are contrary to the object and purpose of the Convention." 121

\section{CRC}

The object and purpose of the CRC can be seen as the protection of the fundamental rights of the child as set out in that convention. All ASEAN states are now party to the CRC, which has 193 parties in total. This convention

119. The précis of discussions between the state and the Committee is drawn from the record of proceedings in Committee Monitoring Compliance with Women's Anti-Discrimination Convention Takes Up Periodic Report of Thailand, U.N. Doc WOM/1531 (20 Jan. 2006).

120. Id. ๑ 4.

121. Concluding Comments of the Committee on the Elimination of Discrimination against Women: Thailand, U.N. Doc. CEDAW/C/THA/CO/5, I 11 (3 Feb. 2006). 
permits reservations in Article 51, providing that reservations "incompatible with the object and purpose of the present Convention shall not be permitted." ${ }^{122}$ The CRC is silent on the legal effect of reservations, and provides for no mechanism whereby there can be objective determination of whether a reservation is in fact valid.

The extent of reservations to this treaty led to the call, in the Vienna Declaration and Programme of Action emerging from the World Conference on Human Rights, to states parties to withdraw those reservations that were contrary to its object and purpose. ${ }^{123}$ The Committee on the Rights of the Child has been engaged on the issue of reservations since its very first meeting. ${ }^{124}$ It has addressed reservations in several general comments. General Comment No. 5 (2003) on general measures of implementation expressed deep concern that some states had made reservations that plainly breached Article 51 (2) by suggesting, for example, that respect for the Convention is limited by the state's existing constitution or legislation, including in some cases religious law. It points out that Article 27 of the Vienna Convention provides that a party cannot invoke its internal law as justification for failure to perform a treaty and encourages other states to lodge formal objections to such wide-ranging reservations. In its general guidelines regarding periodic reports, the World Conference on Human Rights asked states to consider reviewing any reservation with a view to withdrawing it, ${ }^{125}$ and to "indicate whether the Government consider[ed] it necessary to maintain the reservations it ha[d] made, if any, or ha[d] the intention of withdrawing them."126 In its guidelines for initial reports under the Optional Protocols, the Committee requested information about the intention of states parties to withdraw any existing reservations.

This Committee has not been very robust in tackling reservations. Writing in 1996, William Schabas described its approach as "cautious." ${ }^{127}$ It is more focused on maximum treaty participation: as early as 1992, it identified as its primary consideration the maintenance of the "spirit of understanding and consensus deriving from the Convention, and stressed that it did not wish to refer to the question of reservations and declarations as a dividing factor which would undermine this spirit."128 While it has assumed the authority to

122. CRC, supra note 17 , art. 51.

123. Vienna Declaration and Programme of Action, supra note 6, Pt. II, \ 5.

124. The Practice of Human Rights Treaty Bodies With Respect to Reservations to International Human Rights Treaties, Seventeenth meeting of chairpersons of the human right treaty bodies, Geneva, 23-24 June 2005; Fourth Inter-Committee Meeting of the human rights treaty bodies, 20-22 June 2005, U.N.Doc. HRI/MC/2005/5, 13 June 2005.

125. Vienna Declaration and Programme of Action, supra note 6, Pt. II, 95.

126. General Guidelines for Periodic Reports, U.N. Doc. CRC/C/58, ๆ 11 (20 Nov. 1996).

127. Schabas, supra note 34 , at 488.

128. Practice of Human Rights Treaty Bodies With Respect To Reservations to International Human Rights Treaties, supra note 56, ๆ 12. 
consider and rule on reservations, it does not do so directly, as will be seen. It has not severed any such reservations which it finds contrary to Article 51 of the CRC. It prefers to root any objections in the Vienna Programme of Action and even NGO consultations in the country (see its Concluding Observations on Malaysia).

\section{ASEAN States' Reservations to CRC}

There are six ASEAN states that have entered, or retain, no reservations limiting their obligations under the CRC (Cambodia, Indonesia, Lao PDR, Myanmar, Philippines, and Vietnam). The remainder have entered reservations to twenty normative articles in Part I of the convention as well as reservations of a general character that apply across the board and are not tied to particular provisions.

\section{PROVISION}

RESERVING STATE

Article 1-Definition of Child

Article 2-Non Discrimination

Article 3-General principles

Article 4-Measures to be taken

Article 5-Parental and other rights

Article 7-Right to a Name and Nationality

Article 9-Right to Parental Access and Family Life

Article 10-Family reunification

Article 13-Freedom of Expression

Article 14-Freedom of Thought, Conscience, Religion

Article 15-Freedom of Assembly and Association

Article 16-Right to Privacy

Article 17-Right to information

Article 18-Parental rights

Article 20-Right to Special Protection and Assistance

Article 21-Adoption

Article 22-Rights of Refugee Children

Article 28-Right to Education

Article 32-Protection from Economic Exploitation

Article 37-Freedom from Torture and Deprivation of Liberty

Malaysia
Malaysia
Singapore
Singapore
Singapore
Malaysia
Thailand
Singapore
Malaysia
Brunei, Malaysia
Malaysia
Singapore
Singapore
Singapore
Brunei
Brunei
Thailand
Singapore, Malaysia
Singapore
Singapore

Three of the four ASEAN states have made reservations of a general cross-cutting nature, with potential impact on all provisions in the treaty. 
Brunei Darussalam

Malaysia

Singapore
Constitution, Islam, State, Religion ${ }^{129}$

Constitution, National Laws, National Policies ${ }^{130}$

Existing Socio-Political Situation, Domestic Law, State ${ }^{131}$

The effect of these catch-all reservations is to allow each of these states a fall-back whenever they do not wish to comply with a CRC obligation to amend laws or practices that are incompatible.

\title{
2. Objections by Other States
}

\author{
The objections to reservations entered to the CRC by ASEAN states have \\ drawn objection exclusively from European states.
}

129. [The Government of Brunei Darussalam] expresses its reservations on the provisions of the said Convention which may be contrary to the Constitution of Brunei Darussalam and to the beliefs and principles of Islam, the State, religion, and without prejudice to the generality of the said reservations, in particular expresses its reservation on articles 14, 20 and 21 of the Convention.

130. The Government of Malaysia accepts the provisions of the Convention on the Rights of the Child but expresses reservations with respect to articles 1, 2, 7, 13, 14, 15, [ . . ], 28, [paragraph 1 (a)] $37,[\ldots]$ of the Convention and declares that the said provisions shall be applicable only if they are in conformity with the Constitution, national laws and national policies of the Government of Malaysia.

131. Declarations: (1) The Republic of Singapore considers that a child's rights as defined in the Convention, in particular the rights defined in article 12 to 17 , shall in accordance with articles 3 and 5 be exercised with respect for the authority of parents, schools and other persons who are entrusted with the care of the child and in the best interests of the child and in accordance with the customs, values and religions of Singapore's multi-racial and multi-religious society regarding the place of the child within and outside the family. (2) The Republic of Singapore considers that articles 19 and 37 of the Convention do not prohibit (a) the application of any prevailing measures prescribed by law for maintaining law and order in the Republic of Singapore; (b) measures and restrictions which are prescribed by law and which are necessary in the interests of national security, public safety, public order, the protection of public health or the protection of the rights and freedoms of others; or (c) the judicious application of corporal punishment in the best interest of the child.

Reservations: (3) The Constitution and the laws of the Republic of Singapore provide adequate protection and fundamental rights and liberties in the best interests of the child. The accession to the Convention by the Republic of Singapore does not imply the acceptance of obligations going beyond the limits prescribed by the Constitution of the Republic of Singapore nor the acceptance of any obligation to introduce any right beyond those prescribed under the Constitution. (4) Singapore is geographically one of the smallest independent countries in the world and one of the most densely populated. The Republic of Singapore accordingly reserves the right to apply such legislation and conditions concerning the entry into, stay in and departure from the Republic of Singapore of those who do not or who no longer have the right under the laws of the Republic of Singapore, to enter and remain in the Republic of Singapore, and to the acquisition and possession of citizenship, as it may deem necessary from time to time and in accordance with the laws of the Republic of Singapore. (5) The employment legislation of the Republic of Singapore prohibits the employment of children below 12 years old and gives special protection to working children between the ages of 12 years and below the age of 16 years. The Republic of Singapore reserves the right to apply article 32 subject to such employment legislation. (6) With respect to article 28.1(a), the Republic of Singapore- (a) does not consider itself bound by the requirement to make primary education compulsory because such a measure is unnecessary in our social context where in practice virtually all children attend primary school; and (b) reserves the right to provide primary education free only to children who are citizens of Singapore. 


\section{RESERVING STATE OBJECTING STATE BASIS OF OBJECTION}

\begin{tabular}{|c|c|c|}
\hline \multirow[t]{12}{*}{ Brunei Darussalam } & Finland & Vagueness or Imprecision \\
\hline & Sweden & Vagueness or Imprecision \\
\hline & & Invocation of Domestic Law \\
\hline & Ireland & $\begin{array}{l}\text { Incompatible with the Object and Purpose of } \\
\text { the Treaty }\end{array}$ \\
\hline & Denmark & $\begin{array}{l}\text { Incompatible with the Object and Purpose of } \\
\text { the Treaty }\end{array}$ \\
\hline & & Invocation of Domestic Law \\
\hline & Germany & Invocation of Domestic Law \\
\hline & Norway & Too Wide \\
\hline & Italy & Invocation of Domestic Law \\
\hline & Portugal & Invocation of Domestic Law \\
\hline & Austria & $\begin{array}{l}\text { Incompatible with the Object and Purpose of } \\
\text { the Treaty unless Reserving State Provides } \\
\text { More Details }\end{array}$ \\
\hline & Netherlands & Invocation of Domestic Law \\
\hline \multirow[t]{16}{*}{ Malaysia } & Belgium & $\begin{array}{l}\text { Incompatible with the Object and Purpose of } \\
\text { the Treaty }\end{array}$ \\
\hline & Denmark & Too Wide \\
\hline & & Invocation of Domestic Law \\
\hline & & $\begin{array}{l}\text { Incompatible with the Object and Purpose of } \\
\text { the Treaty }\end{array}$ \\
\hline & Austria & $\begin{array}{l}\text { Incompatible with the Object and Purpose of } \\
\text { the Treaty unless Reserving State Provides More } \\
\text { Details }\end{array}$ \\
\hline & Norway & Too Wide \\
\hline & & Vagueness or Imprecision \\
\hline & & $\begin{array}{l}\text { Incompatible with the Object and Purpose of } \\
\text { the Treaty }\end{array}$ \\
\hline & Sweden & Invocation of Domestic Law \\
\hline & Germany & Invocation of Domestic Law \\
\hline & Finland & Too Wide \\
\hline & & Vagueness or Imprecision \\
\hline & & $\begin{array}{l}\text { Incompatible with the Object and Purpose of } \\
\text { the Treaty }\end{array}$ \\
\hline & Netherlands & Invocation of Domestic Law \\
\hline & Ireland & $\begin{array}{l}\text { Incompatible with the Object and Purpose of } \\
\text { the Treaty }\end{array}$ \\
\hline & Portugal & Invocation of Domestic Law \\
\hline \multirow[t]{9}{*}{ Singapore } & Portugal & Invocation of Domestic Law \\
\hline & Finland & Vagueness or Imprecision \\
\hline & & Invocation of Domestic Law \\
\hline & & $\begin{array}{l}\text { Incompatible with the Object and Purpose of } \\
\text { the Treaty }\end{array}$ \\
\hline & Belgium & Invocation of Domestic Law \\
\hline & Germany & Invocation of Domestic Law \\
\hline & Italy & Invocation of Domestic Law \\
\hline & Netherlands & Invocation of Domestic Law \\
\hline & Norway & $\begin{array}{l}\text { Incompatible with the Object and Purpose of } \\
\text { the Treaty }\end{array}$ \\
\hline \multirow[t]{2}{*}{ Thailand } & Ireland & Invocation of Domestic Law \\
\hline & Sweden & $\begin{array}{l}\text { No Clarification for the Finding of } \\
\text { Incompatibility }\end{array}$ \\
\hline
\end{tabular}


Of the ten states objecting to Brunei-Darussalam's reservations, three found them clearly incompatible with the object and purpose of the CRC, and six used the more delicate form of expressing doubts about its commitment to the object and purpose of the Convention. Two states, Finland and Denmark, severed the reservations. None of the nine objecting states declared there to be no treaty relations with Brunei Darussalam.

Ten states objected to Malaysia's reservations. Five did so in unequivocal terms, such as Finland declaring that they "clearly" were incompatible with the object and purpose of CRC. Four states expressed doubts about Malaysia's commitment to the treaty. Three of the objecting states severed the reservation: Belgium, Denmark, and Finland. Denmark pointed out that the reservations covered multiple provisions, including central provisions of the treaty, as did Finland. None of the nine objecting states opposed the entry into force of the treaty with Malaysia.

Seven states objected to Singapore's reservations (including its two declarations). Three of these found the reservations without a doubt incompatible, and four caused the objecting states to express doubts about Singapore's commitment to the object and purpose of the CRC. The Netherlands pointed out that the second of Singapore's declarations was impermissible for impacting on the fundamental nature of the rights protected in Article 19 and 37. Finland, Belgium, and Norway severed the reservations, and no state opposed the entry into force of the treaty with Singapore.

Two states objected to Thailand's reservations. Ireland objected on the grounds that it created doubts about that state's commitment to the object and purpose of the treaty. Sweden found the reservations to Articles 9(2), 15(3), and 16 to be incompatible with the object and purpose of the CRC. Neither state severed the reservations and none opposed the entry into force with Thailand. None of the reserving states responded to the objections.

\section{ASEAN States, their Reservations and the Committee on the Right of the Child}

Brunei-Darussalam appeared before the Committee on the Rights of the Child on 25 September 2003 to present its initial report. ${ }^{132}$ The Committee's country rapporteur expressed concern about the two types of reservations that the state had entered: the general reservations in relation to its constitution and Islamic principles and the specific reservations to articles pertaining to freedom of thought, conscience and religion, protection of a child without a family, and adoption. The state responded that since Islam was the main

132. Initial Reports of States Parties: Brunei Darussalam, U.N. Doc. CRC/C/61/Add.5 (20 Dec. 2001). The précis of the state's discussions with the Committee is taken from the record of proceedings in Press Release: UN Committee on the Rights of the Child Reviews Initial Report of Brunei Darussalam (25 Sept. 2003). 
principle on which the country was based, the reservations were made in accordance with Islamic doctrine as well as its constitution. However, it was stressed Brunei-Darussalam had not failed in its efforts to promote and protect the rights of children. In its Concluding Observations of 27 October 2003, the Committee expressed its deep concern "that the broad and imprecise nature of the state party's general reservation potentially negates many of the provisions and principles of the Convention as to its compatibility with the object and purpose of the Convention, as well as the overall implementation of the Convention." ${ }^{\prime 133}$ It strongly recommended re-examination of the reservations with a view to withdrawing them.

Malaysia presented its initial report to the Committee on the Rights of the Child on 25 January 2007. ${ }^{134}$ The state was forthcoming about its inability to fulfill all of its obligations under the Convention, but stressed that this did not mean the will was not there. Implementation was proving more difficult than simply amending laws. Questioned about its non-ratification of other human rights conventions, Malaysia's Head of Delegation explained that its $C R C$ ratification had required a huge undertaking to conform with the ensuing treaty obligations, involving amending its legislation. The state had not been able to complete it and that looked bad. He stressed that it was not lack of interest or lack of concern about the issues raised in the various human rights conventions, but the difficulty of preparing Malaysian law to be in conformity with them. On the withdrawal of the reservations to the CRC, Malaysia reported that it had imposed certain internal timeframes for that to happen, but did not want to share them for fear of promising what could not be delivered. In relation to the reservation to Article 37, Malaysia was already committed to withdrawal as caning or whipping was unacceptable, against the CRC and there were no problems foreseen with amending the Child Act to reflect that. In its concluding observations of 2 February 2007, the Committee noted with appreciation the efforts to review some of its reservations and emphasized that:

$[M]$ any of the reservations are, with regard to the progress made in the adaptation of the legislation to the requirements of the Convention and in the light of the Vienna Declaration and Programme of Action adopted by the World Conference on Human Rights of 1993, not necessary as also concluded at the Forum on Malaysia's reservations to the Convention on the Rights of the Child which was held on 25 September 2005. ${ }^{135}$

133. Committee on the Rights of the Child, $34^{\text {th }}$ Session, Consideration of Reports Submitted by States Parties under Article 44 of the Convention, Concluding Observations: Brunei Darussalam, U.N. Doc. CRC/C/15/Add.219, If 4 (27 Oct. 2003).

134. The following summary of the discussions is drawn from the record of proceedings in the UN Committee on the Rights of the Child (CRC), UN Committee on the Rights of the Child: Concluding Observations, Malaysia, 25 June 2007, U.N. Doc. CRC/C/MYS/CO/1.

135. Committee on the Rights of the Child, $44^{\text {th }}$ session, Consideration of Reports Submitted by States Parties Under Article 44 of the Convention, Concluding Observations: Malaysia, U.N. Doc. CRC/C/MYS/CO/1, ๆ 9 1, 12 (25 June 2007). 
It called on Malaysia to expedite its review with a view to withdrawing all of the reservations. It also encouraged Malaysia to ratify or accede to the other major international human rights instruments.

Singapore's initial report to the Committee on the Rights of the Child was considered on 26 September 2003. ${ }^{136}$ Singapore declared itself strongly in support of the spirit and objectives of the Convention, and shared the universal vision of a world that was safe, secure, and nurturing of children. Her accession to the CRC signaled its commitment to uphold the rights and best interests of children in the country. Singapore sought to develop in its children a sense of their own social responsibility, as it believed that rights should be accompanied by civil responsibility. Its reservations and declarations were made in areas where they were required by the country's particular national circumstances and social context. There was a belief that the rights and best interests of the child were best served if the nation, community, and family continued to grow in strength. However, Singapore stressed that its reservations in no way impeded vigorous and committed action on the part of the government and society to ensure that the spirit and substance of the CRC was upheld and the best interests of the child were upheld. Singapore insisted that its reservations and declarations were entered in accordance with the special circumstances of its society. Singapore believed that it could only accept the obligations that it could fulfill. Singapore considered that a child's rights as defined in the Convention, in particular the rights defined in Articles 12 to 17, should be exercised with respect for the authority of parents, schools, and other persons who were entrusted with the care of the child and in the best interests of the child. Concerning the reservations, the constitution and the laws of Singapore provided adequate protection and fundamental rights and freedoms in the best interests of the child. Accession to the Convention did not imply the acceptance of obligations going beyond the limits prescribed by the constitution or the acceptance of any obligation to introduce any right beyond those prescribed under the constitution. Singapore would only accept obligations that it could abide by and it could only accept what it could really accomplish. It could not promise to review its position on the reservations and declarations but would continue to do what it could. On 27 October 2003, the CRC Committee made its Concluding Observations, expressing concern about Singapore's declarations and reservations, and calling for their withdrawal in light of the Vienna Declaration and Programme of Action. ${ }^{137}$

136. Initial Report of Singapore, U.N. Doc. CRC/51/Add.8. The following summary of the proceedings is drawn from the record in Press Release, UN Committee on the Rights of the Child Considers Initial Report of Singapore (29 Sept. 2003).

137. Committee on the Rights of the Child, $34^{\text {th }}$ session, Consideration of Reports Submitted by States Parties Under Article 44 of the Convention, Concluding Observations: Singapore, U.N. Doc. CRC/C/15/Add.220 (27 Oct. 2003). 
On 24 January 2006, the Committee on the Rights of the Child examined Thailand's second periodic report. ${ }^{138}$ The Committee raised the contradictions in the government's attitude. On the one hand, it was undergoing reforms and was committed to children's rights, but on the other hand it still retained reservations to the CRC. The delegation explained that many discussions had been held favoring the withdrawal of the two reservations, and it was now a question of working together with the authorities responsible for the decision making. Various improvements had been done to carry through the spirit of Articles 7 and 22. A new policy was already in the process of implementation to register everyone regardless of whether they were living in Thailand legally or illegally. In its Concluding Observations, the Committee noted that progress had been made but regretted the maintenance of reservations. The Committee also pointed out that Thailand had ratified Articles 7 and 22 of the ICCPR without having made any such reservations. Thailand was recommended to withdraw the reservations in line with the Vienna Declaration and Plan of Action of the World Conference. ${ }^{139}$

\section{Optional Protocol to the Convention on the Rights of the Child on the Involvement of Children in Armed Conflict}

The Optional Protocol was adopted by Resolution A/RES/54/263 of 25 May 2000 at the fifty-fourth session of the General Assembly of the United Nations. It seeks to regulate more stringently the participation of children in armed conflict, specifically raising the minimum age to eighteen years.

There are 122 states that are party to it, including five ASEAN members: Cambodia, Lao PDR, the Philippines, Thailand, and Vietnam. Indonesia and Singapore have signed but not ratified. None of the ASEAN states that are party have entered reservations, although Cambodia, Lao PDR, and the Philippines have made declarations. No objections were lodged against them.

\section{E. Optional Protocol to the Convention on the Rights of the Child on the Sale of Children, Child Prostitution and Child Pornography}

The Optional Protocol was adopted by Resolution A/RES/54/263 of 25 May 2000 at the fifty-fourth session of the General Assembly of the United Nations.

138. Committee on Rights of Child Considers Second Periodic Report of Thailand (in French) (24 Jan. 2006). The following précis was taken from the notes of the proceedings compiled by the NGO Group for the Convention on the Rights of the Child, available at http://crin.org/docs/CRC41_Thailand.doc.

139. Committee on the Rights of the Child, $41^{\text {st }}$ Session, Consideration of Reports Submitted by States Parties Under Article 44 of the Convention, Concluding Observations: Thailand, U.N. Doc.CRC/C/THA/CO/2 (17 Mar. 2006). 
It seeks to criminalize the sale of children, child prostitution, and child pornography.

There are 117 parties to this Optional Protocol, including Cambodia, Lao PDR, Thailand, and Vietnam. Indonesia is only a signatory. Article 5, dealing with extradition for crimes under the Optional Protocol, attracted reservations from Lao PDR (Article 5(2)) and Vietnam (Article 5 (1) to (4)). There were no objections.

\section{ASSESSMENT OF THE IMPACT OF ASEAN STATES RESERVATIONS TO HUMAN RIGHTS TREATIES AND THE ASEAN COMMISSION ON WOMEN AND CHILDREN}

\section{A. No Common Standard}

All of the ASEAN states are party to CEDAW and CERD, but their cherrypicking of legal obligations through use (misuse) of the permissive reservations regime has created a complex patchwork of different undertakings. The foregoing section revealed that there is no common standard binding all ASEAN states in the matter of women and children. One cannot even identify a lowest common denominator, a minimum core within the minimum core of rights laid down in the conventions, because even those articles that have not been specifically reserved against are potentially caught under the sweeping "catch-all" reservations by certain states.

The waters are muddied further by the unresolved issues surrounding the many ASEAN state reservations that have been declared by other states or the treaty monitoring bodies as being incompatible with the object and purpose of the treaty. Some ASEAN states, such as Cambodia, Vietnam, Lao PDR, the Philippines, and Myanmar, are bound by the two conventions in their entirety. Finally, some states are also party to optional protocols to CEDAW and CRC, others are not.

\section{B. Are States that Enter Reservations any Worse or Better than States that do not?}

There are many ways of measuring human rights compliance. ${ }^{140}$ In 1998, the CEDAW Committee suggested that reservations to any human rights treaty "clearly indicate the degree of commitment of the reserving state to

140. See Todd Landman, Measuring Human Rights: Principle, Practice and Policy, 26 Hum. RTs. Q. 906 (2004). 
full compliance with the particular treaty." ${ }^{141}$ Based on what has emerged in the periodic state reports and dialogue with the committees culminating in the Concluding Observations (admittedly a minimalist form of monitoring and ensuring compliance), one cannot conclude that states that have entered no reservations, or that have removed existing ones, are doing any better in promoting and protecting human rights than those that have entered extensive reservation. One cannot say that Myanmar and Cambodia, with no reservations to either treaty, are doing better on the rights of their women and children than Singapore, with its very significant reservations. As observed in relation to CEDAW, Thailand (which has progressively pruned down its reservations over the years) was accused by a committee member of taking its treaty obligations lightly. If anything, the detailed explanations put forward by states with reservations, such as Malaysia and Singapore, suggest that they are taking their treaty obligations seriously. On the other hand, it may of course be that it is the opportunity to present the most positive picture of the state that is being taken seriously. The point may need to be made that the size of the delegation that is sent to Geneva does not equal commitment to human rights. Untimely reports do not bode well, but there may be a variety of understandable reasons for late submissions. Finally, buying into United Nations human rights jargon of benchmarks, tools, action plans, building blocks, and roadmaps does not equal compliance.

Some of the ASEAN states with reservations, such as Thailand and Malaysia, do indicate that they are making efforts to remove their reservations. Singapore is not making any concessions whatsoever; its periodic reports consist of arguments about how what is done in Singapore on the basis of the existing system is fully consistent with the Convention. Singapore will only accept obligations which it can fulfill, it has told the CRC Committee. Accession did not imply acceptance of any obligations going beyond its constitution. Using the periodic reporting exercise as a yardstick, it is hard to see that the non-reserving states (Philippines, Cambodia, Myanmar, Indonesia, and Vietnam), are doing better on protecting women and children than Brunei Darussalam, Thailand, Singapore, or Malaysia with their reservations. A very different survey than this study is required to establish whether the protection of women and children has actually improved since these states became party to the treaties. Oona Hathaway's research found that:

Although the ratings of human rights practices of countries that have ratified international human rights treaties are generally better than those that have not, noncompliance with treaty obligations appears to be common. More paradoxically, when I take into account the influence of a range of other factors that affect countries' practices, I find that treaty ratification is not infrequently associated

141. Report of the Committee on the Elimination of Discrimination Against Women 18th, 19th Sess., UN CEDWA, U.N. Doc.A/53/38/Rev.1. 
with worse human rights ratings than otherwise expected. I do, however, find evidence suggesting that ratification of human rights treaties by fully democratic nations is associated with better human right practices. ${ }^{142}$

\section{Is ASEAN still a bastion of relativism?}

The data suggest not anymore. Only four of the ten ASEAN states still hold on to some form of a relativism justification for not meeting the demands of international human rights law: Malaysia, Singapore, Brunei Darussalam, and Thailand. Adding to the impression that the opposition to human rights on relativist grounds in ASEAN has become marginal, is the fact that one-time Asian values champion Indonesia, has now withdrawn all its reservations to CEDAW and CERD.

Within the four "relativists" there is considerable distance; this is no monolithic block. The reservations are not about ASEAN values or Asian values, but instead about the particular circumstances in the country and its society. Thailand has been progressively removing its reservations to CEDAW (seven out of nine reservations were removed over sixteen years), but says it has had difficulty with ordinary citizens and prevailing attitudes about the role of women in Thai society. It appears to be struggling to maintain the right balance of its culture and traditions, with international norms on the rights of women. Singapore's arguments suggest that its society is straddling a sensitive yet correctly calibrated economic, cultural, socioeconomic balance that will not withstand tampering, whether in relation to women or children. Singapore claims to share the same objectives as other states parties, but its society has certain views on bringing up children, and the role of parents and society in the welfare and best interests of the child. Singapore's reports and explanations show no willingness to review or reconsider the situation. Brunei Darussalam also shows no signs of movement on its reservations to the two treaties. Malaysia asserted to the CEDAW Committee that it had made reservations because parts of the convention were not compatible with its domestic law, yet was reviewing the situation with respect to some of those reservations. On the other hand, it explained to the CRC Committee the difficulties in preparing Malaysian law to be in conformity with the CRC, assuring them that it was not about lack of will. The Head of Delegation assured the CRC Committee in January 2007 that internal deadlines had been set for removal of the reservations.

If there is a link, it is between the three states that raise Islamic law-Brunei Darussalam, Malaysia, and Singapore raising the situation of minority

142. Oona A. Hathaway, Do Human Rights Treaties Make a Difference?, 111 YaLE L. J. 1935, 1940 (2002). 
Muslim population. This seems to be a line which none of these states is prepared to cross.

\section{What about customary international law and obligations erga omnes?}

Malaysia's reservation to the non-discrimination provision of CEDAW raises interesting issues concerning peremptory norms and obligations erga omnes. Malaysia reads womens' property rights in CEDAW as subject to Shariah law on the division of inherited property. It reads equality in employment as being subject to certain public offices like the Mufti Shariah Court Judges, and the Imam which is in accordance with the provisions of the Islamic Shariah law. The right to marriage and family life is subject to Shariah law and the laws of Malaysia, under which the age limit for marriage for women is sixteen and men is eighteen. This, it will be recalled, was declared by objecting states and the Committee as being incompatible with the object and purpose of the Convention.

To date, it is only racial discrimination that is recognized as being a norm imposing obligations erga omnes. ${ }^{143}$ Is this to be resolved by way of reference to Article 53 of the Vienna Convention, which deals with treaties conflicting with peremptory norms of international law, not reservations? The Human Rights Committee has made its position clear that reservations that offend provisions which reflect peremptory norms, or even customary norms, are incompatible with the object and purpose of a treaty (General Comment No. 24). ${ }^{144}$ But for the ILC's Special Rapporteur, reservations to customary norms are not invariably contrary to a treaty's object and purpose. ${ }^{145}$ However, he argues that in "the absence of clear justification, therefore, it is impossible for the other contracting parties or for monitoring bodies to verify the validity of the reservation, and it is best to adopt the principle that any reservation to a provision which formulates a rule of jus cogens is null and void ipso facto." ${ }^{146}$ For him, Article 53 of the Vienna Convention applies not only to treaty relations but to "all legal acts, including unilateral acts." 147 He is now proposing a guideline providing that states "may not formulate a reservation to a treaty provision which sets forth a peremptory norm of general international law." ${ }^{\prime 48}$ Professor Hampson also takes the view that no

143. See Barcelona Traction, Light and Power Company, Limited, Second Phase, (Belgium v. Spain) Judgment, ICJ Reports 32, I ๆ 33-34 (5 Feb. 1970).

144. Also see comment on this in the Hampson Final Working Paper, supra note 50, I 54.

145. Tenth Report on Reservations to Human Rights Treaties by Alain Pellet, Special Rapportuer, First Addendum, U.N. Doc.A/CN.4/558/Add.1, 14 June 2005, ๆ ๆ 116-46.

146. Id. ๆ 136.

147. Id. ๆ 135.

148. See Text of Draft Guidelines annexed to the Second Addendum of Tenth Report by Alain Pellet, supra note 51 at Guideline 3.1.8, 3.1.9, 3.1.10. 
reservation to a norm of jus cogens character would be valid, unlike with customary norms. ${ }^{149}$

The next question is, is there a rule of international law dealing with discrimination per se? The prohibition against discrimination on prohibited grounds (race, sex, or religion) can be traced through treaties such as the International Covenant on Civil and Political Rights (Articles 2, 26), the International Covenant on Economic Social and Cultural Rights (Article 2(3)), International Labour Organisation Convention No. 111 Concerning Discrimination in respect of Employment and Occupation (1958), the UNESCO Convention Against Discrimination in Education (1966) European Convention on Human Rights (Article 13) and American Convention on Human Rights back to the UN Charter (Articles 1(2) and 13(1)), and the Universal Declaration of Human Rights (Articles 1,2, 4,7) which is of course not binding in itself. Non-discrimination as to race, sex, language, or religion in the promotion and encouragement of respect for human rights and fundamental freedoms is one of the objectives of the United Nations, and as such, under Article 103 of the Charter, will take precedence to other international obligations (arguably including those limitations set down in reservations). Non-discrimination clauses listing prohibited grounds are included in many national constitutions, such as Article 12 of Singapore's Constitution and Article 39 of Hong Kong's Basic Law incorporating the International Covenant on Civil and Political Rights. Many countries have laws prohibiting discrimination (albeit on their own terms). In their practice, states will rarely acknowledge unlawful differential treatment (discrimination) in their jurisdiction, but will seek to justify offending conduct in terms of lawful differential treatment. This strongly suggests that the norms protecting equality, and prohibiting discrimination on certain grounds in addition to race, are customary, but whether they have entered the realm of obligations erga omnes is debatable.

The data suggests that there are three areas where it is possible that new customary rules on reservations may be developing (lex in statu nascendi). For the avoidance of doubt, this study does not claim there is the necessary degree of consistent and uniform state practice and opinio juris that is needed to prove the existence of new rules of customary international law; there are however signs of possible evolution in that direction in the three areas. The first relates to a possible regional custom evolving among the Nordic states (and shared by other non-Nordic states): Finland, Denmark, Norway, and Sweden, to object to reservations to human rights treaties that are, or appear to be, contrary to the object and purpose of the treaty. Some of these states are inclined, despite the futility of the gesture, to declare such reservations severed in order in an attempt to make the point that the state making invalid reservations cannot benefit from them.

149. Hampson, Final Working Paper, supra note 50, ฯ 51. 
The second area of interest relates to reservations that subject international obligations to the constitution or domestic law. As this study has shown, this is a common form of reservation. It is very often met by the objection that it is not permissible to raise domestic law as an excuse for non-compliance with international undertakings. Both the CEDAW and CRC Committees, as well as objecting states, have commented on it in light of Article 27 of the Vienna Convention. But as has been rightly argued by Schabas, Article 27 has nothing to do with reservations, but to do with performance of treaty obligations. ${ }^{150}$ It comes in Part III of The Vienna Convention on Observance, Application and Interpretation of Treaties, in Section 7. Observance of treaties only comes into play once the extent of the state's obligations have been determined, i.e., once the issue of reservations has been addressed and resolved. One cannot just "transpose" the rule as was suggested in discussions at the International Law Commission. ${ }^{151}$ Yet a wide range of states are persistently making the claim that it is not permissible to use domestic law as an excuse for not meeting international obligations in relation to reservations. This is something worth watching; it may signal a change in the customary rule.

The third area of interest relates to objections to the generality or vagueness of a reservation. The objections in this area seem to draw from the practice of the European Court of Human Rights and Article 64 of the European Convention on Human Rights, which prohibits reservations of a general nature. It should be noted that Professor Pellet is proposing a Guideline 3.1.7, whereby reservations worded in vague, general language which does not allow its scope to be determined is incompatible with the object and purpose of the treaty. ${ }^{152}$

\section{E. Locating the ASEAN Reservations to CEDAW and CRC in the wider doctrinal disputes}

The examples examined in this article cut to the heart of the contemporary dispute over reservations to human rights treaties. This article has examined a number of states that have sought to limit their treaty obligations. Under current international law, they may do so, as it is a fundamental principle that states cannot be bound to what they did not consent to. Both CEDAW and CRC permit reservations with the usual limitations, but do not require that acceptance by other states is the condition for permissibility.

150. Schabas, supra note 34 , at 480 .

151. See Report of the International Law Commission on the Work of its Forty-Ninth Session, supra note 35, ๆ 140.

152. See Text of Draft Guidelines annexed to the Second Addendum of Tenth Report by Alain Pellet, supra note 51, Guideline 3.1.7. 
Apart from Thailand's CRC reservation, each ASEAN state entering reservations to CRC or CEDAW drew objections from at least one other state, ${ }^{153}$ because of the compatibility of that reservation with the object and purpose of the treaty itself. In three cases: Brunei Darussalam, Malaysia, and Thailand and their CEDAW reservations, every objecting state found the reservations to be clearly incompatible. Other reservations drew a mix of outright and nuanced denunciation. The reasons given for objecting are not just based on incompatibility with object and purpose. They include the width of the reservation, vagueness, or imprecision and invocation of domestic law. In addition, the two Committees have made their views clear. Whatever the legal consequences, Brunei Darussalam, Malaysia, Singapore, and Thailand have been found to have entered reservations that run contrary to the object and purpose of CEDAW and CRC.

But what about the other states that stayed silent? Given the signs of a concerted practice among some of the Nordic states and some other European states such as Ireland and Portugal, what of others like the United Kingdom and France? Some states, such as the US, are not regular objectors (which may have something to do with the fact that it is a regular maker-of-reservations). In 1989, the Rosalyn Higgins suggested that silence in the face of incompatible reservations may amount to collusion. ${ }^{154}$ Another view is that it is more that states just cannot be bothered to do so if there is no need to object, or no benefit is to be derived from lodging an objection. ${ }^{155}$ In the absence of reasoned explanation in each situation, one can but speculate.

The human rights treaty and Vienna Convention based regimes, with no permanent independent mechanism expressly authorized to appraise and act upon reservations, have resulted in a vacuum. As noted, every single state objecting to the reservations of Brunei Darussalam, Malaysia, and Thailand to CEDAW did so on unequivocal grounds of incompatibility with the object and purpose of the treaty. But what could they do beyond the empty political gesture of lodging an objection? Saying that the treaty does not apply at all is of no use in human rights treaties, where one wants maximum treaty participation and the objecting state has no interest in using the reservation itself. The only option of the reserving states to maintain participation and preserve integrity of the treaty is to sever the reservation. This in itself is an act of uncertain value given that severance is not provided for in the

153. It should be noted that some of the objecting states have themselves resorted to reservations, so their objections are not rooted in a belief that there should be no reservations to human rights treaties. For instance, Austria, Germany, and the Netherlands made reservations to CRC.

154. Rosalyn Higgins, The United Nations: Still a Force for Peace, 52 Modern L. Rev. 1, 11-12 (1989).

155. Yogesh Tyagi, The Conflict of Law and Policy on Reservations to Human Rights Treaties, 71 BRITISH Y.B. INT'L L. 181, 215 (2000). 
treaty or the Vienna Convention regime and thus may have no practical effect. It will be recalled that the treaty's design allows not for severance of the reservation, but maintenance of the reservation despite the objections. The reality is that the reserving states are continuing to benefit from their reservations: the practice of Brunei Darussalam, Malaysia, Singapore, and Thailand, including the responses of the committees, make it clear that they continue to be parties to the treaties on the terms that they have set and that the objections of other states are irrelevant.

There are no special rules for human rights treaties. Some states, such as Singapore, make it clear that joining on their terms is the price of participation in the treaty. Others, such as Thailand and Malaysia, indicate that they are working towards removal of some or all of the reservations. None of the states with controversial reservations challenge objections or complaints from the treaty bodies that their reservations go right to the heart of the treaty. Instead, they focus on justifying the necessity for such limitations. The ASEAN states' reservations to the normative provisions of CEDAW and CRC have been to specific provisions or are general in nature. In the latter case, the state explains the limitation of its treaty obligation on one or several grounds: the constitution, national laws, Islam/religion, state/national policies, or existing socio-political conditions in the country.

The objections thereto allege these reservations to be either vague or imprecise, improperly raise internal laws, too wide, or simply incompatible with the object and purpose of the treaty. To be precise, some of the objections are ultimately subsumed under a finding of incompatibility. But overall, the practice is evidence that compatibility is not the only standard for objecting to reservations. The objecting states also made the following observations about the ASEAN reservations:

1. Such reservations undermined the basis of international human rights treaties.

2. Such reservations undermined the basis of international treaty law.

3. They expressed doubts about the state's commitment to fulfill its treaty obligations.

4. It is in the common interest of states that are party to a treaty to make the necessary legislative changes and to fulfill the object and purpose of the treaty.

5. It is in the common interest of states that treaties to which they have chosen to be parties should be respected as to the object and purpose.

From this small study alone, we see layers of bilateral relationship that emerge from the reservations of ASEAN states to CEDAW and CRC, and the objections thereto. There are some situations where the Vienna Convention provides guidance: reservations to which states that have not taken the opportunity to object to (under Article 20(5), silence will be deemed to be 
acceptance of the reservation, which then applies in full between the parties) and where states that have objected on compatibility grounds but not objected to the treaty entering into force between them or have expressly stated that the treaty does enter into force between them (under Article 20(4)(b) and 21(3), in the absence of definite expression of an intention that the treaty does not enter into force, it will do so, but without the provision to which the reservation attaches). Where a state has simply expressed doubts about the compatibility of the reservation with the object and purpose of the treaty, the reservation will apply in its bilateral relationship with that other state. The legal relationship is unclear where states that have not objected because they believe it unnecessary to object to invalid reservations, and where states that have objected on compatibility grounds have severed the reservation or stated that the treaty applies in full between themselves and the reserving state. As far as these reserving ASEAN states are concerned, the factual reality is that their reservations apply no matter what the de jure situation may be.

From a formal legal perspective, the effect of the ASEAN reservations and objections depends on one's doctrinal perspective. Quarrelling about doctrine may be fun for some academics, but it is hardly satisfactory for the states and practitioners who usually just want to know what the law is and to get on with applying it. Even the ILC is unable to take a position. Professor Pellet asserts that this ongoing and perhaps insoluble doctrinal quarrel reveals ambiguities and uncertainties about reservations that the Vienna Convention cannot resolve. ${ }^{156}$ If one follows the permissibility school, these reservations are invalid, null and void from the start and the objection of a state would simply be confirmatory. Following the opposability school, a reservation that is incompatible with the object and purpose of the treaty is only invalid if another state objects on that ground. Under the Vienna Convention system, even such an objecting state would have to repudiate treaty relations for the reservations to be void of legal effect. And, even then, it would only be on a bilateral basis. At the end of the day, in practical terms, no matter what doctrinal position one follows, it is quite clear that these ASEAN states, specifically Brunei Darussalam, Malaysia, Singapore, and Thailand, remain parties to the treaties that they have filed controversial reservations to. They regard their international obligations as subject to their reservations, most forcefully expressed by Singapore. All are engaged as parties to the two treaties, for example attending the meetings of states parties to the two treaties, reporting and engaging in dialogue with the treaty bodies with a view to attaining the objects and purposes of the treaties. The two treaty bodies express concern about the reservations and call on the states to withdraw

156. ILC, Report on the Work of Its $48^{\text {th }}$ Session, 6 May-26 July 1996, If 55; see also First Report of the Special Rapporteur, ๆ 96-115. 
them, but do not challenge the state's proceeding on the basis that its treaty obligations are subject to its reservation. Not one of the objecting states treats them as non-party to the treaty, in spite of the strength of some of the objections to the reservations on grounds of incompatibility. To sum up, in the world of CEDAW and the CRC, a limitation that is incompatible with the object and purpose of the treaty is in fact treated as a reservation. ${ }^{157}$ The reserving state is allowed to rely on that reservation; objections from other states play only a symbolic role.

ASEAN states, not surprisingly in light of their common policy on non-intervention, do not enter objections or make comments about the reservations of other states. The European states are much more active, and appear to be behaving in a concerted manner. From this study, there is not a common EU position, but it is clear that the same states consistently make their objections on the same issues, at least in relation to ASEAN states. Severance of the reservation by an objecting state is a feature of the objections entered by some Nordic states, notably Finland and Denmark, suggesting a possible regional custom in evolution. ${ }^{158}$ As noted earlier, this is probably as far as states can go in the human rights system, where reciprocity makes no sense. None of the objecting states felt strongly enough to declare the non-existence of treaty relations. This is not surprising, given that human rights treaties are not about the personal interests of states but go towards protection of the human person within the jurisdiction of each party. As such, the objecting state has no personal interest in declaring there to be no treaty relations between itself and the reserving state. Its wider policy interest is to ensure that states, such as those in ASEAN who have been hesitant about participation in human rights treaties, do actually take part. We do not have any responses from reserving states; they continue to maintain the reservations until, as in the cases of Thailand and Indonesia, they are able to withdraw them.

157. See observations of the United Kingdom on General Comment No. 24, United Kingdom's Observations, Report of the Human Rights Committee, GAOR, 50 th Session (1995), Supp. No. 40, U.N. Doc.A/50/40, that incompatible reservations fall outside the scope of Articles 20 and 21 entirely, available at http://www.un.org/documents/ga/docs/50/plenary/a50-40.htm.

158. This practice can be traced back to the Geneva Conventions of 1949. Hampson Final Working Paper, supra note 50, ๆ 16, 17; see also Id. \ 30, for consideration of the reasons behind the active Western European and Others group in lodging objections; See Klabbers, supra note 46. 


\section{WITHER THE ASEAN COMMISSION ON WOMEN AND CHILDREN?}

We seem to be in the midst of what international relations theorists call a norms cascade in ASEAN — support for a particular norm gathers slowly until it reaches a threshold or "tipping" point, after which the adoption by other states in the region of that norm occurs more rapidly and leads to a "cascade" effect. ${ }^{159}$ There has certainly been a shift in the perceived legitimacy of the international norms protecting the human person. But it is important to distinguish between norm-recognition with norm-compliance. ASEAN states may now have begun taking an active part in the life of human rights treaties such as CEDAW and CRC, but their compliance records show there is a long way to go before the treaty obligations are met. ASEAN states do not yet appear to be willing to submit to a truly independent and powerful supervisory human rights body in their own backyard. After all, only one state-the Philippines - has consented to an individual petition mechanism offered by a treaty system.

Even if there is a norms cascade, the challenges for those working on human rights in ASEAN continue to be very significant. Aspirations for a better future for human rights in ASEAN states must be tempered with realism. The possibility of a human rights mechanism began to be heard in ASEAN discourse as long ago as 1993. Yet in 2007, the discussions remain aspirational. ASEAN still speaks of the possibility of such a mechanism, although it is now stamped with the seal of respectability by being officially recommended by the Eminent Persons Group. The Vientiane Action Plan has taken up the notion of a Commission on Women and Children. At the moment, it does not look like the ASEAN Charter itself will entrench a women and children's commission or any other human rights mechanism. But we must remember that a graduated approach in regional systems is not unusual. When states in the Americas created the Organization of American States (OAS) in 1948, they did so via the Charter of the Organization of American States. This charter had a significant focus on human rights: democracy, economic rights, the right to education, and equality, complementing the American Declaration of the Rights and Duties of Man which all the states also signed. The OAS Charter also established the Inter-American Commission on Human Rights as the principal human rights institution within the organization. It was only in 1978 that the Inter-American Court of Human Rights came into being with the entry into force of the 1969 American Convention on Human Rights. The Declaration continues to be the standard by which states that are not party to the American Convention on Human Rights are bound. Today's African Union is the successor of the Organiza-

159. Martha Finnemore \& Kathryn Sikkink, International Norm Dynamics and Political Change, 52 Int'l Org. 887 (1998); Free Markets and Social Justice (Cass R. Sunstein ed., 1997). 
tion of African Unity (OAU), established on 25 May 1963. It was almost twenty years later that the OAU adopted the African Charter on Human and People's Rights in 1981 as its primary human rights instrument. And this came with significant "clawback clauses" for the state at the expense of the rights protected. The Charter led to the establishment of the African Human Rights Commission, charged with ensuring the promotion and protection of human and peoples' rights in Africa. The African Union succeeded the OAU and the African Economic Community in 2001. Its objectives include the promotion and protection of "human and peoples' rights in accordance with the African Charter on Human and Peoples' Rights and other relevant human rights instruments." The African Court on Human and Peoples Rights was only established twelve years after the entry into force of the African Charter, and its judges appointed in 2006. Implementation of human rights in a new ASEAN may well follow such a leisurely pace; this is a debate that has after all, been running since 1993 .

Lowest common denominators are lethal for the integrity of normative instruments on human rights. Even so, it has been demonstrated in this article that the general cross-cutting reservations coming on top of the article-specific ones, result in the absence of a common standard of obligation among ASEAN states. Even if one were to compromise, one cannot compromise when there is no discernable bottom line. Furthermore, designing an ASEAN commission drawing in states that have limited their treaty obligations through invalid reservations, will be creating a "value minus" institution ("value plus" being a buzzword used in ASEAN NGO circles). ${ }^{160}$ Bending over backwards to accommodate them would be akin to a renegotiation of the terms of CERD and CEDAW. If such a weak mechanism went ahead, what is to be done about those controversial reservations? It is worth noting that no CEDAW based referrals to the International Court of Justice have ever been made; in any event, treaty-based dispute resolution clauses are not popular among ASEAN states (although five of them have now turned to international courts for settlement of their disputes). ${ }^{161}$ Given their sensitivity on sovereignty, it is unlikely that these states will consent to a powerful and independent Commission on Women and Children with authority not just to comment on their reservations, but also to make binding findings on the effect thereof.

160. Vitit Muntarbhorn, Co-Chair of the Working Group for an ASEAN Human Rights Mechanism, argues that the "value-added" of an ASEAN commission on women and children would be to nurture regional responses to issues pertaining to the rights of women and children and lift the standards of states' behavior in these areas, see Report of the Expert Meeting on the Establishment of an ASEAN Commission for the Promotion and Protection of the Rights of Women and Children, supra note 14, at 2.

161. Cambodia, Thailand, Malaysia, Singapore, and Indonesia have all had or are having disputes heard by the International Court of Justice. The number rises to six if one considers the Philippines' attempt to intervene in the Sipadan-Ligitan dispute. 
It would be a waste of time to create a commission to function as a talk-shop, but whether in the current political climate there can be anything as intrusive as judicial scrutiny or individual petition is questionable, not just from the political will angle but on grounds of effectiveness. A number of ASEAN states are using the International Court of Justice to settle their disputes, but their preference is to be non-confrontational and cooperate with each other. This feeds into the well-established ASEAN policy of noninterference.

From a legal and policy perspective, it is clear that any sacrifice of the integrity of CEDAW and CRC in the pursuit of ASEAN's first, and hopefully not only, human rights mechanism or a sui generis ASEAN perspective on women and children (which will be a repackaging of the passé Asian Values position), needs to be strenuously resisted. In light of the issues examined in this article, if CEDAW and CERD are not to be watered down, there can only be one option for a Commission on Women and Children based on a Charter or other foundational document setting out the legal framework-it must have as its minimum standard the entire normative content of CEDAW and CRC, with no option for reservations. ${ }^{162}$

This would mean only the six ASEAN states (Cambodia, Indonesia, Lao PDR, Philippines, Myanmar, and Vietnam) that have unfettered participation in those treaties should participate in an ASEAN Commission for Women and Children. ${ }^{163}$ The others should only be able to join when they have aligned their treaty obligations with the six, but obviously they will need to be given some incentive to do so. However, the issues are not so clear cut. For example, if the lives of Singapore's women and children are indeed already so fulfilled, why would they need to take part in an ASEAN Commission on Women and Children on top of regularly explaining themselves to the committees in Geneva? Singapore is one of those states that can, it seems, manage on its own, and it may well see no incentive to join a regional commission. For other countries, an incentive would be concrete and substantial assistance in helping states meet their treaty based obligations, and helping those already doing well to go further. The CEDAW and CRC periodic reporting processes clearly reveal that the six non-reserving ASEAN states continue to need enormous assistance in meeting their pacta sunt servanda obligations. The gaps that exist between reporting, monitoring,

162. The CRC optional protocols are not sufficiently supported to warrant their inclusion at this stage, but given that several of these states have allowed the right of individual petition to treaty monitoring bodies, an optional complaints assessment function is possible.

163. Such a treaty would prohibit reservations or it could fall under Article 20(2) of the Vienna Convention, under which reservations must be accepted by all the parties, because the limited number of negotiating states and the object and purpose of the treaty requires its application in its entirety between all the parties as an essential condition of the consent of each one to be bound by the treaty. 
and implementation need to be plugged. This is a clear role for the Commission, and it also relates directly to greater regional cooperation in human rights and the realization of an ASEAN identity. Anticipating and resisting use of a Commission on Women and Children as an excuse-whether for not establishing a wider regional mechanism, not removing reservations, or not becoming party to core human rights treaties or optional protocols allowing for individual petition-is also immensely important. Ensuring the coherent whole in line with the other principal human rights treaties and preventing duplication of efforts with the existing treaty-monitoring bodies and the national human rights commissions (Philippines, Thailand, Indonesia, and Malaysia have commissions that do significant work on women and children; Cambodia is working towards establishing one) are just some of the many other matters that will need to be carefully considered in the design of the commission. An ASEAN commission could certainly be given a lead role in the drafting and implementation of treaties that crystallize cooperation in, for example, trafficking of women and children, sex tourism, child prostitution, pornography, and adoption etc. Such activities are of the type that can certainly supplement CEDAW and CERD. The ultimate goal is of course to enhance the protection of the human person in ASEAN by entrenching human rights. But to duplicate efforts, make unrealistic demands or overburden states would be counterproductive in that slow step-by-step journey that ASEAN states are now making in the world of human rights. 